\title{
Shadow Sovereign Ratings \\ For Unrated Developing Countries
}

\author{
Dilip Ratha, Prabal De and Sanket Mohapatra* \\ Development Prospects Group \\ World Bank
}

\begin{abstract}
The authors attempt to predict sovereign ratings for developing countries that do not have risk ratings from agencies such as Fitch, Moody's, and Standard and Poor's. Ratings affect capital flows to developing countries through international bond, loan and equity markets. Sovereign rating also acts as a ceiling for the foreign currency rating of sub-sovereign borrowers. As of the end of 2006, however, only 86 developing countries have been rated by the rating agencies. Of these, 15 countries have not been rated since 2004. Nearly 70 developing countries have never been rated. The results indicate that the unrated countries are not always at the bottom of the rating spectrum. Several unrated poor countries appear to have a ' $B$ ' or higher rating, in a similar range as the emerging market economies with capital market access. Drawing on the literature, the analysis presents a stylized relationship between borrowing costs and the credit rating of sovereign bonds. The launch spread rises as the credit rating deteriorates, registering a sharp rise at the investment grade threshold. Based on these findings, a case can be made in favor of helping poor countries obtain credit ratings not only for sovereign borrowing, but for sub-sovereign entities' access to international debt and equity capital. The rating model along with the stylized relationship between spreads and ratings can be useful for securitization and other financial structures, and for leveraging official aid, for improving borrowing terms in poor countries.
\end{abstract}

Keywords: Sovereign rating, country risk, capital market, securitization, development finance

World Bank Policy Research Working Paper 4269, June 2007

The Policy Research Working Paper Series disseminates the findings of work in progress to encourage the exchange of ideas about development issues. An objective of the series is to get the findings out quickly, even if the presentations are less than fully polished. The papers carry the names of the authors and should be cited accordingly. The findings, interpretations, and conclusions expressed in this paper are entirely those of the authors. They do not necessarily represent the view of the World Bank, its Executive Directors, or the countries they represent. Policy Research Working Papers are available online at http://econ.worldbank.org.

${ }^{*}$ This research was carried out when Prabal De was a summer intern at the World Bank. We are grateful to Alan Gelb, Suhas Ketkar and Vikram Nehru for extensive discussion, and to David Garlow, Luis Luis, Greg Sutton, the participants at World Bank seminars organized respectively by the Financial Policy and Country Creditworthiness Department, South Asia Chief Economist's Office, the Debt Department, Development Prospects Group, and the Kennedy School of Government, for useful comments and suggestion. Thanks to Zhimei Xu for excellent research assistance. Please email comments to dratha@worldbank.org. 


\section{Shadow Sovereign Ratings \\ For Unrated Developing Countries}

\section{Introduction}

The credit rating issued by major international rating agencies such as Fitch, Moody's, and Standard and Poor's is a key variable affecting a sovereign's or a firm's access to capital markets. Risk ratings not only affect investment decisions in the international bond and loan markets, but they also affect allocation of foreign direct investment and portfolio equity flows. The allocation of performance-based official aid is also increasingly being linked to sovereign rating. ${ }^{1}$

The foreign currency rating of the sovereign - which has the authority to seize foreign exchange earnings, impose exchange restrictions, fix exchange rates, and even expropriate private assets - typically acts as a ceiling for the foreign currency rating of sub-sovereign entities (Beers and Cavanaugh 2005, Truglia and Cailleteau 2006, Fitchratings 1998, Lehmann 2004). Even when the sovereign is not issuing bonds, a sovereign rating provides a benchmark for capital market activities of the private sector. "The rating process, as well as the rating itself, can operate as a powerful force for good governance, sound market-oriented growth, and the enforcement of the rule of law. From a business perspective, sovereign credit ratings serve as a baseline for evaluating the economic environment surrounding investment possibilities and as a benchmark for investors to distinguish among markets, which provides valuable information and a basis for evaluating risk" (US Department of State 2006).

It is worth noting, however, that as of today, 70 developing countries - mostly poor - and 12 high-income countries do not have a rating from a major rating agency. ${ }^{2}$ Of the 86 developing countries that have been rated, the rating was established in 2004 or earlier for 15 countries. A few countries do not need a rating as they do not need to borrow. Most of the unrated countries, however, do need external credit, and resort to relationship-based borrowing from commercial banks, or selling equity to foreign direct investors. Because of their ongoing relationship with the borrowers, banks can monitor the latter's willingness and ability to repay debt. Bond investors, on the other hand, rely heavily on standard indicators such as credit ratings to monitor the borrower. The cost of borrowing from international capital markets is inversely related to the sovereign rating. For a $\$ 100$ million, 7-year bond in 2005, the launch spread would rise from 27 basis points

\footnotetext{
${ }^{1}$ See International Development Association (2006a and 2006b). Kaminsky and Schmukler (2002) provide evidence of the influence of sovereign ratings on portfolio equity returns. See also Reinhart (2002a); Claessens and Embrechts (2002); and Ferri, Liu and Majnoni (2001).

${ }^{2}$ Many countries are rated by export credit agencies, insurance agencies and international banks. But these ratings are tailored for internal use in these institutions and meant for specific purposes such as short-term trade credit). They may not be useful for risk evaluation by general institutional investors.
} 
for a 'A-' bond to 577 basis points for a ' $\mathrm{CCC}+$ ' rated bond (box 1). There is a sharp jump in spreads (of 91 basis points in 2005) at the investment grade threshold. ${ }^{3}$

When arms-length monitoring of investment projects is difficult, non-bank investors either do not invest, or take direct control of the investment project via FDI. Also, the cost of financing FDI projects is affected by sovereign risk ratings. In 2005, FDI constituted 85 percent of private capital flows in the unrated countries compared to 26 percent in the BBB rated developing countries (figure 1). ${ }^{4}$

Figure 1: Composition of private capital flows in rated and unrated countries, 2005

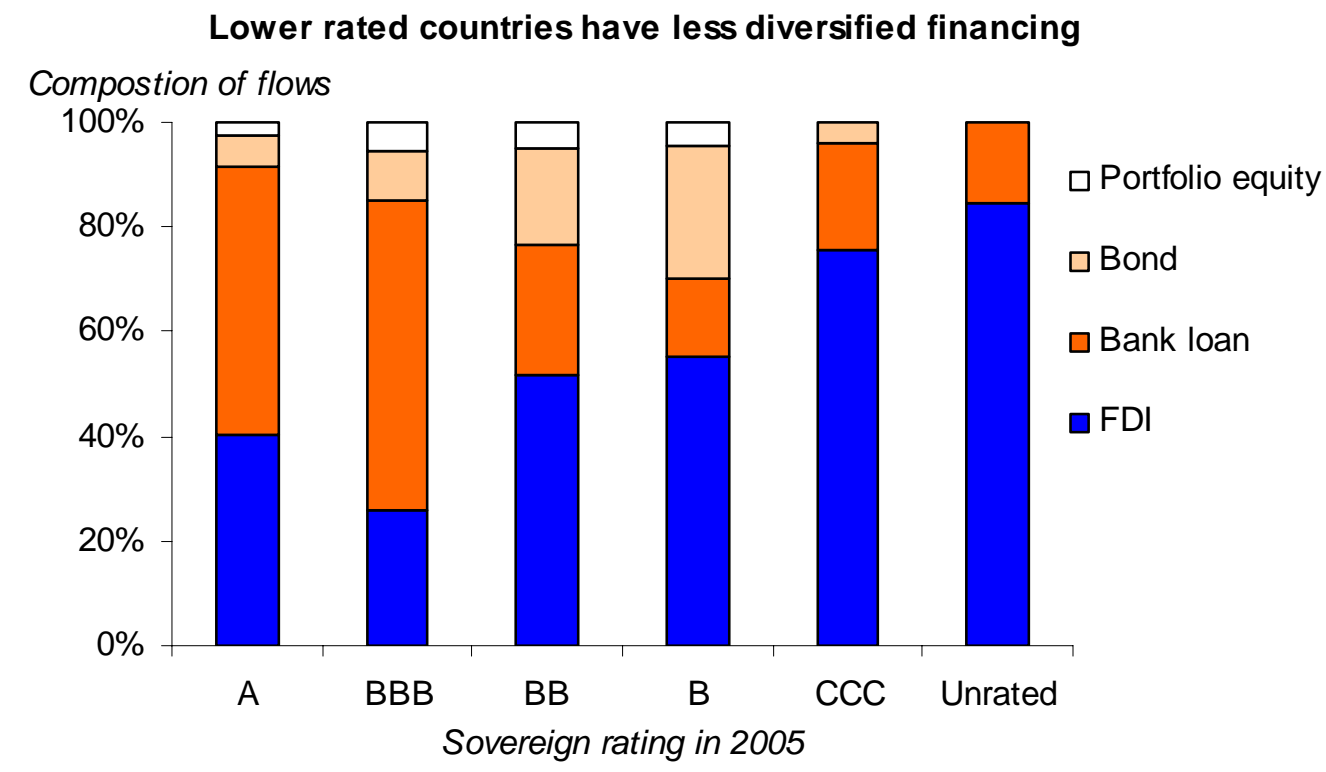

Source: World Bank, Global Development Finance 2006 database.

Several factors influence a country's reluctance or inability to get rated. Countries are constantly reminded of the risks of currency and term mismatch associated with market-based foreign currency debt, and the possibility of sudden reversal of investor sentiment (Panizza, Eichengreen and Hausmann 2005, Calvo and Reinhart 1999). The information required for the

\footnotetext{
${ }^{3}$ This sharp jump reflects the limitations or regulations that prevent institutional investors from buying subinvestment grade. Knowing where a country lies on the credit spectrum can give some idea about the cost of capital. For poor countries that are rated below investment grade, an improvement in rating (via financial structuring or proper accounting of hard currency flows such as remittances) could result in significant spread savings, in the range of 300-700 basis points depending on the initial rating and global credit market conditions.

${ }^{4}$ Fernández-Arias and Hausmann (2001) argue that a higher share of FDI—and a correspondingly lower share of private debt flows - may be an indicator of poorly functioning markets, inadequate institutions and high risks. The authors find a higher FDI share in countries that are poorer, riskier, more closed, more volatile, less financially developed, and with weaker institutions and more natural resources. Loungani and Razin (2001) report a similar negative relationship between Moody's country ratings and FDI share.
} 
rating process can be complex and not readily available in many countries. ${ }^{5}$ The institutional and legal environment governing property rights and sale of securities may be absent or weak, prompting reluctance on the part of politicians to get publicly "judged" by the rating analysts. The fact that the country has to request a rating, and has to pay a fee for that, but has no say over the final rating outcome can also be discouraging. ${ }^{6}$ Also Basel capital adequacy regulations that assign a lower risk weight (100 percent) to unrated entities than to those rated below BB- (150 percent) may discourage borrowing entities from getting rated.

Having no rating, however, may have worse consequences than having a low rating. Unrated countries are often perceived by creditors as riskier than they are, than even very high default risk countries. In 2002, the US Department of State, Bureau of African Affairs decided to fund a project to help African nations get an initial sovereign credit rating (US Department of State 2006). The United Nations Development Program (UNDP) recently partnered with Standard and Poor's to rate 8 African countries during 2003-2006 (Standard and Poor's 2006a and UNDP 2006). Interestingly, the newly established ratings under these two initiatives did not fall at the bottom of the rating spectrum. Of the 10 newly rated African countries, 1 was rated BB-, and the rest rated in ' $\mathrm{B}$ ' categories, and none was rated ' $\mathrm{C}$ '.

In this paper, we hope to make a modest contribution to these efforts by estimating a model of sovereign ratings for rated developing countries using readily available variables, and then attempting to "predict" sovereign ratings for the unrated developing countries.

The plan of the paper as follows. In the next section, we present some stylized facts about sovereign ratings. We show that ratings by different agencies are highly correlated with a correlation coefficient of 0.97 or higher! We also find that ratings for individual countries tend to be sticky over time, a fact that brought criticism to the rating industry in the aftermath of the Asian crisis (Ferri, Liu and Stiglitz 1999). In section 3, we develop the rating prediction model, drawing on the existing literature. We also discuss the results on predicted or shadow sovereign ratings for the unrated countries in this section. The concluding section summarizes the results, and discusses how poor country entities could improve their borrowing terms through financial structuring or leveraging official aid.

${ }^{5}$ For example, Fitch's questionnaire for government officials includes 128 questions in 14 categories (ranging from demographic and educational factors to trade and foreign investment policy), all of which require supporting documentation, past data for 5 years and 2-year ahead forecasts (FitchRatings 1998).

${ }^{6}$ The rating process is initiated by a sovereign (or sub-sovereign) entity. After the signing of the initial contract with a rating agency, which also involves a fee, the rating agency sends out a detailed questionnaire to the entity. Analysts from the rating agency visit the entity and collect information about institutional, economic and political environment. The rating committee comprising these and other analysts compare the entity being rated against other entities, and decide a rating. If the borrowing entity does not agree with the rating, it could request reconsideration, but the rating committee may or may not alter its rating decision. At the final stage, the borrowing entity may request that the rating not be published. Otherwise, the rating is made available publicly to potential investors. 


\section{Box 1: Sovereign spreads are inversely related to sovereign ratings}

The logarithm of spreads can be modeled as a function of sovereign ratings, a dummy that takes the value 1 if a country is considered investment grade, debt issue size and maturity (Cantor and Packer 1996, Eichengreen and Mody 1998, Kamin and von Kleist 1999):

$$
\begin{array}{r}
\left.\log (\text { Spread })=\alpha+\beta_{1} \text { (Investment grade dummy }\right)+\beta_{2}(\text { Sovereign rating }) \\
+\beta_{3}(\log (\text { Issue size }))+\beta_{4}(\text { Maturity })+\text { error }
\end{array}
$$

This model seems to work well in explaining the launch spreads of emerging market sovereign bonds issued during 2003-2005. All the coefficients have the expected sign and, except for issue size, are statistically significant. The adjusted $\mathrm{R}^{2}$ ranges from 0.74 in 2003 to 0.88 in 2005 (box table 1)

\section{Box figure 1: Relation between sovereign ratings and launch spreads}

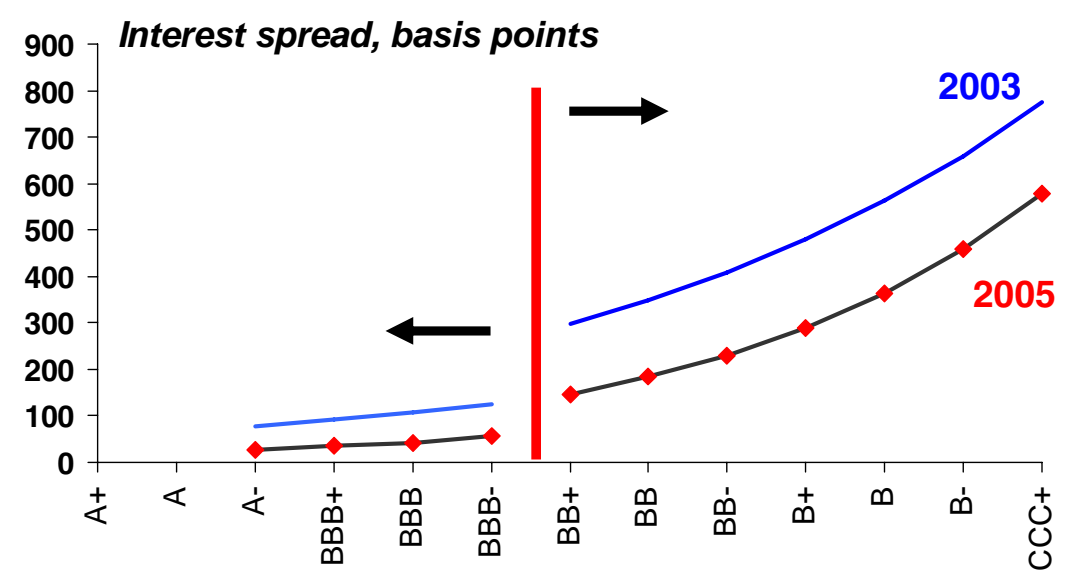

$\$ 100$ million sovereign bond issue with a 7 years tenor.

Sources: Bondware, S\&P, and authors' calculations.

Box table 1: Regression results: relationship between launch spread and sovereign rating

Dependent variable: Log (Launch Spread)

Investment grade dummy

S\&P sovereign rating (numeric equiv.)

$\log ($ Issue size $)$

Maturity (yrs)

Number of observations

Adjusted R-squared

$*$ significant at $10 \% ; * *$ significant at $5 \% ; * * *$ significant at $1 \%$. White robust standard errors are reported below coefficient estimates.

2003

$-0.69 * *$

$(0.33)$

$0.16 * * *$

0.04

$(0.13)$

$0.02 *$

$(0.01)$

37

0.74

2005

$-0.76^{*}$

(0.38)

$0.23^{* * *}$

(0.05)

0.05

(0.08)

$0.03^{* * *}$

(0.01)

42

0.88

( 


\section{Some stylized facts about sovereign credit ratings}

Sovereign credit ratings in some form have been in existence for nearly a century. The major rating agencies - Standard and Poor's and Moody's — started rating sovereign Yankee bonds in the early 20th century. By 1929, 21 countries were rated by Poor's Publishing, the predecessor to S\&P, and even included several of today's emerging markets, e.g. Argentina, Colombia, Uruguay (Bhatia 2002). Moody's started rating debt instruments in 1919, and within the next decade had rated bonds issued by about 50 governments (Cantor and Packer 1995). However, demand for ratings declined during the Great Depression and most ratings were suspended in the period following World War II. Rating activity revived briefly in the post-war period, but declined again in the late 1960s with the introduction of the Interest Equalization Tax (IET), a 15 percent levy on the interest from cross-border lending in the United States (Bhatia 2002). Rating activity for sovereigns resumed from the mid-1970s onwards with the withdrawal of the IET in 1974. In 1980, there were eight high-income countries that were rated by one or the other of the three leading rating agencies viz. Moody's, Standard and Poor's (S\&P) and Fitch. By the late 1980s, almost all the high-income OECD countries had been rated.

Sovereign credit ratings for the developing countries (as currently defined by the World Bank) began in the late 1980s, after the debt crisis (figure 2). The number of rated countries increased significantly during the 1990s emerging market phenomena. By December 2006, 131 countries - 45 high-income and 86 developing countries - were rated by one or more of the three premier agencies.

Figure 2: Evolution of sovereign credit ratings in 1980-2006

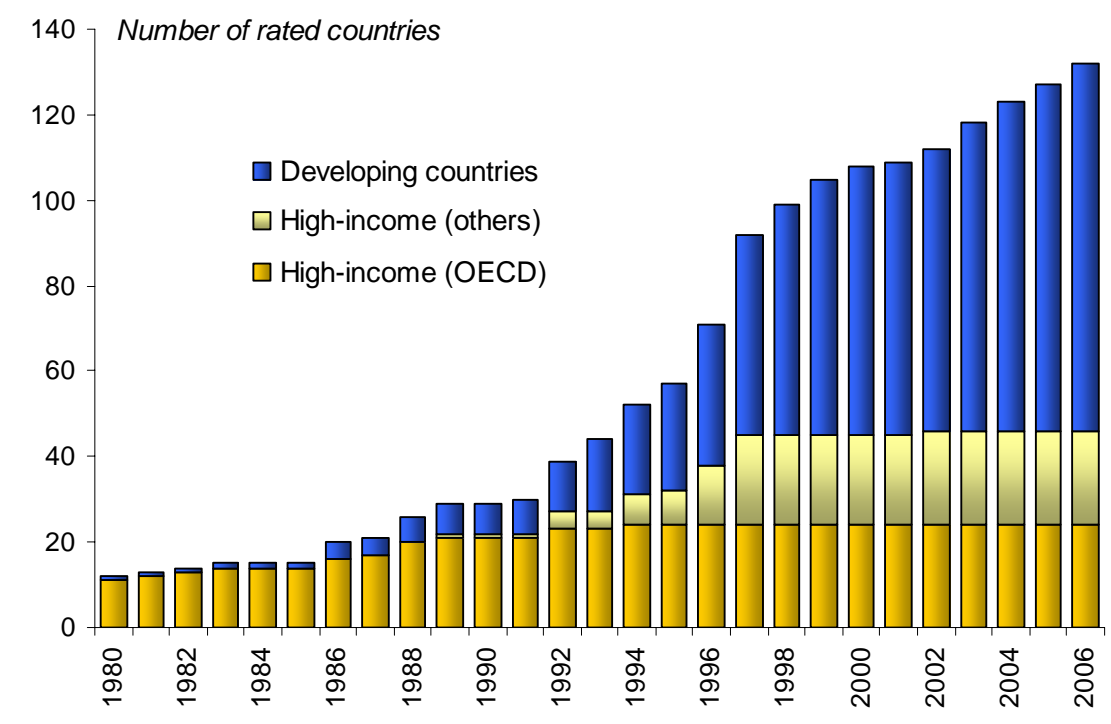

Sources: Standard and Poor's, Moody's, Fitch Ratings, and authors' calculations.

Sovereign ratings issued by different agencies tend to be highly correlated. The bivariate correlation coefficient between the ratings of the three agencies as of December 2006 ranged from 0.97 to 0.99 (figure 3). The ratings are exactly the same across the three agencies for most AAA-rated countries. For most developing countries, the ratings are similar across the three 
agencies, usually within one to two notches of one another. The differences (if any) are typically due to the different timings of ratings.

Figure 3: Sovereign ratings by different agencies are highly correlated - the correlation coefficient ranges between $0.97-0.99$

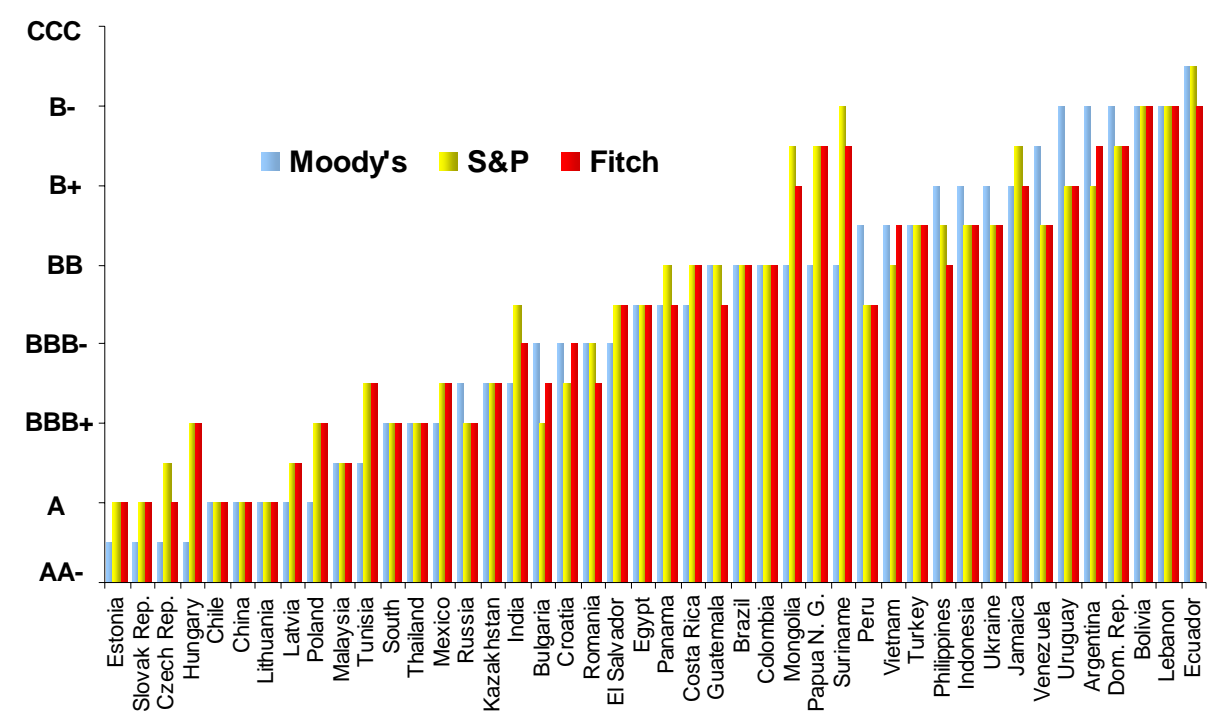

Source: Standard and Poor's, Moody's and Fitch Rating. The figure shows ratings as of December 6, 2006 for developing countries rated by all three rating agencies.

An examination of rating changes over time reveals stickiness (figure 4) reflecting the fact that re-rating does not occur with any regularity, but only when a country requests (and pays for) it, or when some significant, unforeseen event prompts the rating agencies to revisit a rating. Changes to ratings announced by different agencies also tend to be similar in direction and magnitude. A rating upgrade (or downgrade) by one agency is typically followed by a similar change by the others, usually with a lag. Rating agencies came under criticism for failing to predict the Asian crisis, and then for downgrading the countries after the crisis which further deepened the crisis (Ferri, Liu and Stiglitz 1999, Reinhart 2002b). Indeed, ratings were not downgraded by Moody's ahead of, or after, the financial crisis in Mexico in 1994/5, and in Turkey in 2000 (figure 4).

Figure 4: Evolution of sovereign ratings in selected countries

Argentina

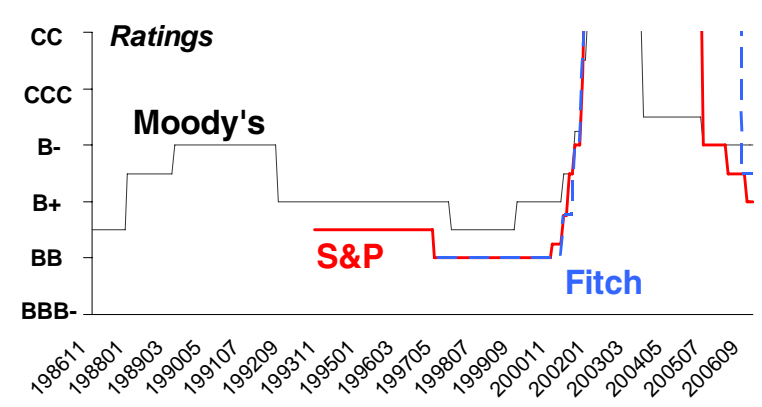

$\underline{\text { Mexico }}$

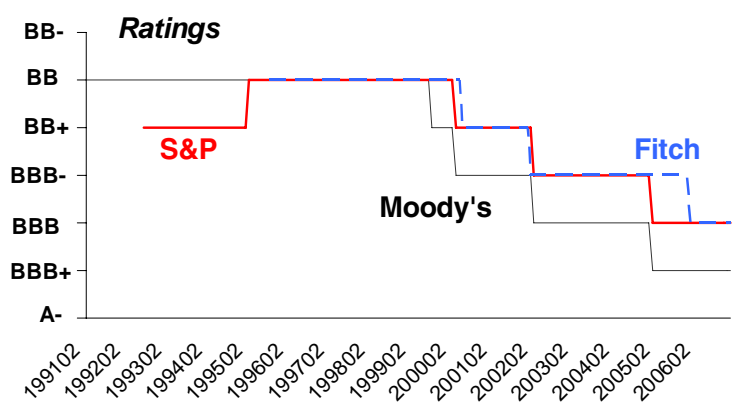


Turkey

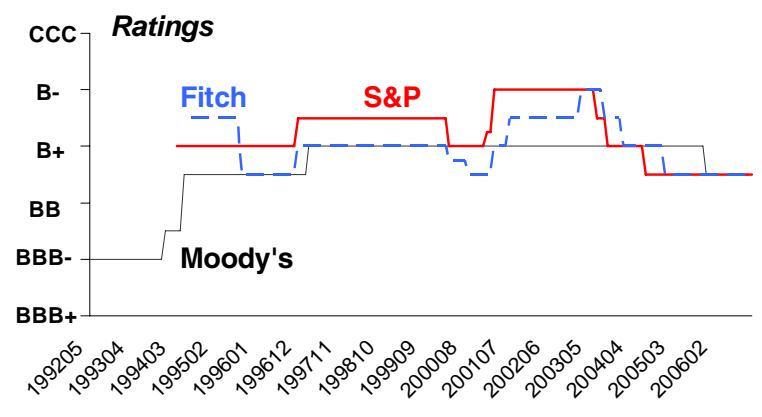

Thailand

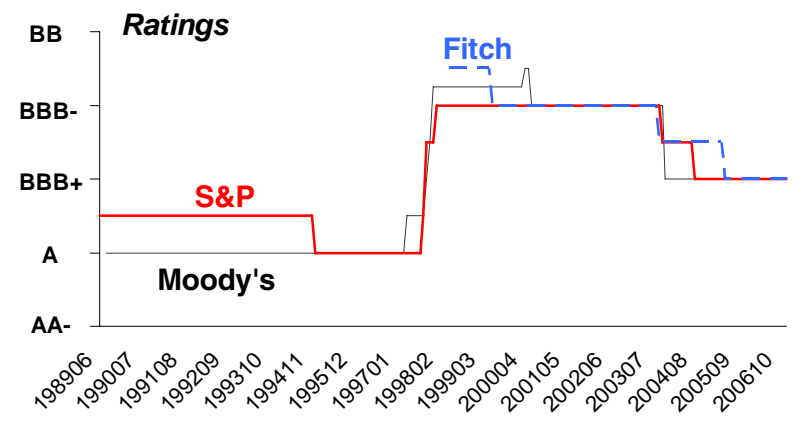

$\underline{\text { Brazil }}$

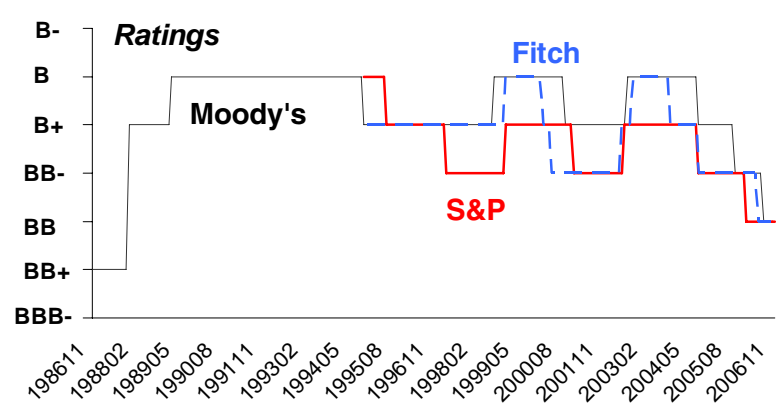

India

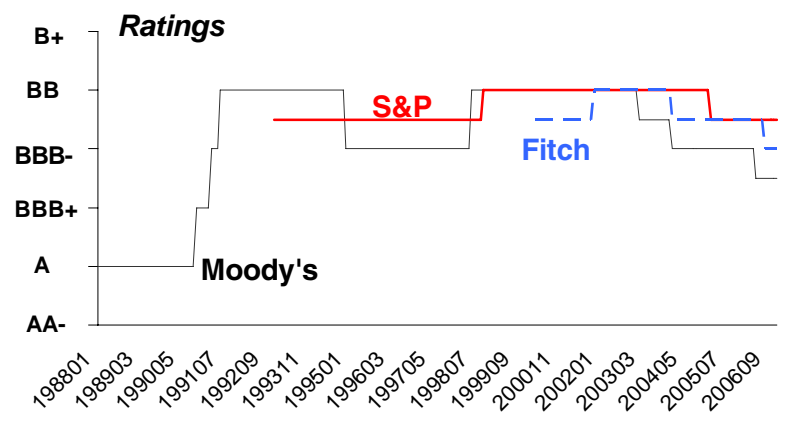

Source: S\&P, Moody's, Fitch Ratings, and authors' calculations. A higher number indicates higher risk and lower letter rating.

In developed countries, a firm's credit risk typically accounts for a large part of the information content of its ratings. In developing countries, however, the sovereign rating exerts significant influence on the ratings of firms and banks located in the country. ${ }^{7}$ Nearly threequarters of sub-sovereign issues that were rated by S\&P during 1993-2005 were rated equal to or lower than the sovereign rating (figure 5). Of these, almost half had exactly the same rating as the sovereign. A small number of sub-sovereign issues did pierce the sovereign foreign-currency rating ceiling, but these issues were mostly by firms in the oil and gas sector (e.g., Pemex, PDVSA, Petronas), or they were structured transactions backed by some form of collateral (such as export receivables and diversified payment rights).

\footnotetext{
${ }^{7}$ Ferri (2003) and Ferri, Liu and Majnoni (2004) provide evidence on the close relationship between the sovereign rating and firm-level credit ratings in developing countries. See also Lehmann (2004).
} 
Figure 5: Sub-sovereign foreign currency debt issues in developing countries rated by S\&P

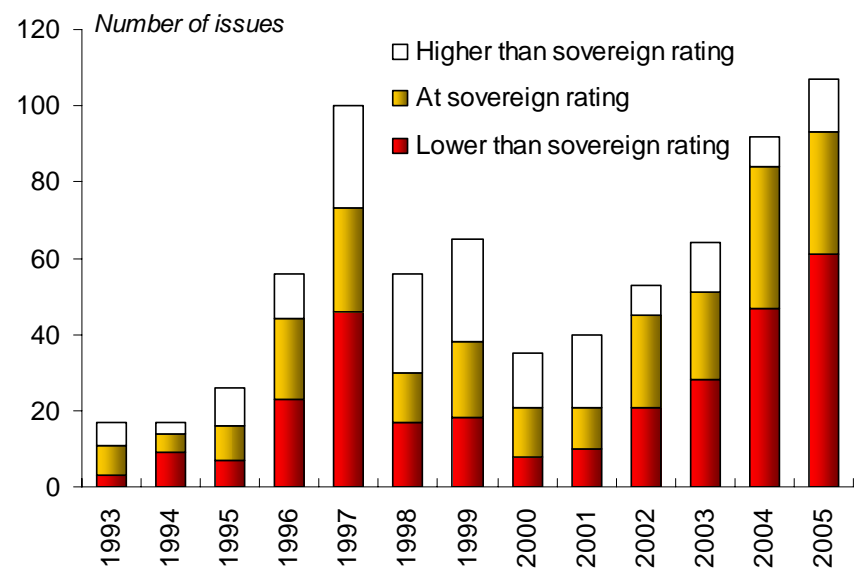

The sample excludes debt issued by supranationals, governments, provinces and local authorities. It includes only debt issued in currencies of high-income OECD countries. We also exclude cases where the sovereign is in default.

Source: Bondware and authors' calculations.

\section{Predicting sovereign credit ratings}

The care, rigor and judgment that go into the sovereign rating process cannot be replaced by any mechanical models. But obtaining ratings from the major agencies for the 70 or so unrated countries would require considerable time and resources. The objective of this section, therefore, is more modest: to attempt to develop an econometric model using readily available variables to generate some preliminary, indicative ratings for the 70 or so unrated countries. The results may be interpreted as a rough indicator of what the actual rating might look like if the country were to get rated by a rating agency.

Rating agencies, due to their business practice, do not officially disclose the precise models used for their rating methodologies. A common practice among rating agencies is to assign qualitative scores to several criteria and then arrive at a weighted average score. Beers and Cavanaugh (2005) provide an excellent explanation of the criteria used by S\&P. They list 44 variables grouped under 10 categories - political risk, income and economic structure, economic growth prospects, fiscal flexibility, general government debt burden, off-budget and contingent liabilities, monetary flexibility, external liquidity, public sector external debt burden, and private sector external debt burden. Similar criteria are also used by Moody's and Fitch (Truglia and Cailleteau 2006, FitchRatings 1998). Both the scoring and the weights used to arrive at the final average rating are influenced by subjective judgment of the rating analysts. Understandably, many analysts believe that country risk ratings should not be determined by mechanical models.

Nevertheless, many researchers have found that the ratings by major agencies are largely explained by a handful of macroeconomic variables (see table 1 for a summary of this literature). Lee (1993) estimated a linear regression model with panel data for 40 developing countries for 
1979-87 using growth, inflation, growth volatility, international interest rates, industrial countries' growth rate, debt to exports ratio, and dummies for geographical location as explanatory variables for ratings. In an often-cited article, Cantor and Packer (1996) used a crosssectional regression model of sovereign credit ratings as a function of per capita income, GDP growth, inflation, fiscal balance and external balance, external debt, default history, and an indicator for the level of economic development. This study used a cross-section of high income and developing countries. Rowland (2005) estimated a similar model using pooled time-series and cross-section data to identify the determinants of sovereign ratings and spreads. Ferri, Liu and Stiglitz (1999) and Mora (2006) used a similar model to examine whether ratings were procyclical during the Asian crisis by comparing predicted with actual ratings. Reinhart, Rogoff and Savastano (2003) estimate similar cross-section and panel regression models for evaluating "debt intolerance", the duress that many emerging market countries experience at debt levels that would seem manageable by industrial country standards.

Sutton (2005) used an instrumental variable estimation in order to tackle the potential reverse causality that runs from ratings to debt burdens. He found little evidence of reverse causality, and concluded that ordinary least squares (OLS) may be the most appropriate technique.

A related literature has examined the determinants of actual debt defaults and debt distress (Kraay and Nehru 2006, Berg and Sachs 1988, Manasse, Roubini and Schimmelpfennig 2003). This literature also finds that a small set of variables (growth, external debt and policy performance) explain the likelihood of debt distress and defaults. ${ }^{8}$

A common finding from this rich set of papers is that sovereign ratings can be explained to a significant extent by a handful of rather easily available macroeconomic variables. In trying to develop a model for predicting sovereign ratings, we proceed in the following manner. First, we estimate the sovereign ratings for the rated developing countries as a function of macroeconomic variables, rule of law, debt and international reserves, and macroeconomic volatility, as identified in the literature. Then we test the predictive power of this model using "within-sample" prediction. We also exploit the high correlation across ratings assigned by the three rating agencies to test whether the predicted rating for one agency is similar to the actual ratings by other agencies. Finally, we use the econometric model to predict ratings for developing countries that did not have a rating as of end-2006.

\footnotetext{
${ }^{8}$ Since most of the unrated countries (for which we predict ratings) are also low-income countries, our paper has some similarities with Kraay and Nehru (2006). However, we employ a continuous numeric scale for ratings and exclude cases of default in our regressions, unlike the use of a 0-1 dummy for debt distress used in Kraay and Nehru.
} 
Table 1: Literature on model-based determinants of ratings

\begin{tabular}{|c|c|}
\hline Lee (1993) & $\begin{array}{l}\text { Dependent variable: sovereign rating (Log of Institutional Investor rating) } \\
\text { Explanatory variables: per capita GDP growth, inflation, international interest rates, } \\
\text { industrial countries' growth rate, variance of per capita GDP growth, debt to exports ratio, } \\
\text { dummies for geographical location, dummy for highly indebted country, and dummy for } \\
\text { major borrower. } \\
\text { Number of observations: } 360 \\
\text { Adjusted } \mathrm{R}^{2}: 0.70 \\
\text { Pooled cross-section and time series of } 40 \text { developing countries for } 9 \text { years (1979-87). }\end{array}$ \\
\hline $\begin{array}{l}\text { Cantor and } \\
\text { Packer (1996) }\end{array}$ & $\begin{array}{l}\text { Dependent variable: sovereign rating (Moody's and S\&P), spread } \\
\text { Explanatory variables: per capita income, GDP growth, inflation, fiscal balance and } \\
\text { external balance, external debt to GDP ratio, default history (dummy for whether a country } \\
\text { defaulted since 1970), and an indicator for the level of economic development (dummy for } \\
\text { industrialized country) } \\
\text { Number of observations: } 49 \\
\text { Adjusted } \mathrm{R}^{2}: 0.91 \text { for Moody's, } 0.93 \text { for S\&P } \\
\text { Cross-section of } 27 \text { high-income and } 22 \text { developing countries in } 1995\end{array}$ \\
\hline $\begin{array}{l}\text { Ferri, Liu and } \\
\text { Stiglitz (1999) }\end{array}$ & $\begin{array}{l}\text { Dependent variable: sovereign rating (Moody's) } \\
\text { Explanatory variables: GDP per capita, real GDP growth, inflation rate, budget deficit, } \\
\text { current account balance, an indicator for debt-sustainability (short-term debt and current } \\
\text { account balance as a ratio of foreign exchange reserves), and an indicator for the level of } \\
\text { economic development (dummy for industrialized country) } \\
\text { Number of observations: } \text { n.a. } \\
\mathrm{R}^{2}: 0.30-0.33 \\
\text { Pooled cross-section and time series of } 6 \text { high-income and } 11 \text { developing countries for } 10 \\
\text { years (1989-98). }\end{array}$ \\
\hline $\begin{array}{l}\text { Reinhart, } \\
\text { Rogoff and } \\
\text { Savastano } \\
(2003)\end{array}$ & $\begin{array}{l}\text { Dependent variables: sovereign rating (Institutional Investor rating) } \\
\text { Explanatory variables: percent of 12-month periods of inflation at or above } 40 \text { percent since } \\
\text { 1948, percent of years in a state of default or restructuring since } 1824 \text {, number of years } \\
\text { since last default or restructuring, external debt/GNP (1970-2000 average), and a dummy } \\
\text { for countries with high ratings. } \\
\text { Number of observations: } 53 \text { for cross-section, } 769-1,030 \text { for panel. } \\
\text { Adjusted } \mathrm{R}^{2}: 0.74-0.79 \text { for cross-section, } 0.78-0.91 \text { for panel regression. } \\
\text { Cross section and panel regressions for } 53 \text { industrial and developing countries for } 1979- \\
2000 \text {. }\end{array}$ \\
\hline
\end{tabular}




\begin{tabular}{|c|c|}
\hline $\begin{array}{l}\text { Rowland and } \\
\text { Torres (2004) }\end{array}$ & $\begin{array}{l}\text { Dependent variables: sovereign rating (Institutional Investor rating), spread } \\
\text { Explanatory variables: GDP growth rate, inflation rate, external-debt to GDP ratio, external } \\
\text { debt to exports ratio, debt service as a share of GDP, the level of international reserves as a } \\
\text { share of GDP, and the openness of the economy (exports and imports as share of GDP) and } \\
\text { a dummy that takes value one for the years in which a country is in default. } \\
\text { Number of observations: } 225 \\
\mathrm{R}^{2}: 0.62 \\
\text { Pooled cross section and time series of } 15 \text { emerging market (developing) countries for } \\
1987-2001 \text {. }\end{array}$ \\
\hline $\begin{array}{l}\text { Rowland } \\
\text { (2005) }\end{array}$ & $\begin{array}{l}\text { Dependent variables: sovereign rating (Moody's, S\&P, Institutional Investor rating), spread } \\
\text { Explanatory variables: GDP per capita, GDP growth rate, inflation rate, external-debt to } \\
\text { GDP ratio, debt-service ratio (ratio of external debt service to current account receivables), } \\
\text { the level of international reserves as a share of GDP, and the openness of the economy } \\
\text { (exports and imports as share of GDP) } \\
\text { Number of observations: } 49 \\
\text { Adjusted } \mathrm{R}^{2}: 0.58 \text { for Moody's, } 0.69 \text { for S\&P } \\
\text { Pooled time-series and cross-section data }\end{array}$ \\
\hline Sutton (2005) & $\begin{array}{l}\text { Dependent variables: sovereign rating (average of Moody's and S\&P) } \\
\text { Explanatory variables: Corruption index, international reserves, ratio of short-term bank } \\
\text { claims to total claims, external-debt to exports ratio, external-debt to GDP ratio, years since } \\
\text { resolution of last default, and a dummy for whether the country was admitted to the EU } \\
\text { Number of observations: } 32 \\
\mathrm{R}^{2}: 0.87 \\
\text { Cross-section of } 32 \text { developing countries in } 2004\end{array}$ \\
\hline Mora (2006) & $\begin{array}{l}\text { Dependent variable: sovereign rating (average of Moody's and S\&P) } \\
\text { Explanatory variables: GDP per capita (PPP), GDP growth, inflation rate, budget balance } \\
\text { (\% of GDP), current account balance (\% of GDP), ratio of external debt to exports of goods } \\
\text { and services, an indicator for the level of economic development (dummy for OECD), } \\
\text { dummies for default on bonds and bank debt, and lagged spread. } \\
\text { Number of observations: } 705 \\
\mathrm{R}^{2}: 0.58-0.68 \\
\text { Pooled cross-section and time series of } 88 \text { countries for 1986-2001. }\end{array}$ \\
\hline
\end{tabular}




\section{Regression model}

As in the literature - notably Cantor and Packer (1996) and Sutton (2005) - we postulate a simple linear regression model in the data of the following form:

$$
\begin{aligned}
\text { Sovereign rating } & =\alpha+\beta_{1}(\log \text { of GNI per capita })+\beta_{2}(\text { GDP growth rate }) \\
& +\beta_{3}(\text { Debt/Exports })+\beta_{4}(\text { Reserves } /(\text { Imports }+ \text { Short-term debt })) \\
& +\beta_{5}(\text { Growth volatility })+\beta_{6}(\text { Inflation })+\beta_{7}(\text { Rule of law })+\text { error }
\end{aligned}
$$

Gross National Income per capita, measured at the current market price, is a proxy for the level of development of a country. The ratio of total reserves to the sum of import and short term debt obligations is a liquidity indicator (originally proposed by Greenspan-Guidotti). A higher value of these variables indicated reduced risk of a default on external obligations. Growth volatility refers to 5-year standard deviation of the GDP growth rate. ${ }^{9}$ The Rule of Law variable is taken from a widely used dataset produced and updated by Kaufmann, Kraay and Mastruzzi (2006). This variable, constructed as a function of various governance indicators such as enforcement of property rights and accountability of the government etc, takes value between -2.5 and +2.5 with higher values indicating better governance. (The world average for this variable is zero.) This variable has also been used by Kraay and Nehru (2006).

We also tried fiscal balance as an explanatory variable in our regressions. However, as in Cantor and Packer (1996) and Rowland (2005), this variable was not statistically significant. This may be due to data problems: the definition of the public sector and the reporting standards for fiscal deficit vary greatly from one country to another. To some extent, the fiscal balance is indirectly reflected in the regression through the other variables such as growth, inflation and external debt. ${ }^{10}$

The dependent variable is the numeric equivalent of the sovereign long term foreign currency rating from one of the three major agencies - Moody's, Standard and Poor's, and FitchRatings. The sovereign ratings issued by the three rating agencies are converted to a numeric scale, with 1 denoting the highest rating (corresponding to AAA for S\&P and Fitch, Aaa for

\footnotetext{
${ }^{9}$ For the empirical analysis, data for most of the right hand side variables are taken from the World Bank's World Development Indicators database and the IMF's World Economic Outlook database. Data on short term and long term claims are collected from the Bank of International Settlements.

${ }^{10}$ We also considered including default history, which has been found to be a significant explanatory variable in several studies (Cantor and Packer 1996, Reinhart, Rogoff and Savastano 2003, Sutton 2005). However, the data on default history is not well defined or does not exist for unrated countries, which typically have no cross-border bond financing and where the data on international bank lending tends to be incomplete. Since our purpose is to predict sovereign rating for unrated developing countries, we include right hand side variables that are readily available from standard data sources for both rated and unrated countries.
} 
Moody's) to 21 being lowest (C for all three agencies). ${ }^{11}$ Table 2 shows the correspondence in the ratings between the three rating agencies. We exclude cases of sovereign default or selective default in our regression analysis since it is difficult to assign a specific numeric rating to such extreme credit events. Although default or selective default appears to be just another step down the road of getting a rating downgrade; assigning a specific value to such an event would run the risk of ignoring the degree of distress (e.g., a temporary liquidity crisis versus a systemic crisis).

\section{Table 2: Ratings - conversion from letter to numeric scale}

\begin{tabular}{|c|c|c|c|}
\hline S\&P & Fitch & Moody's & Numeric Grade \\
\hline \multicolumn{4}{|c|}{ Investment Grade } \\
\hline \multicolumn{4}{|c|}{ Highest credit quality } \\
\hline AAA & AAA & Aaa & 1 \\
\hline \multicolumn{4}{|c|}{ Very high credit quality } \\
\hline $\mathrm{AA}+$ & $\mathrm{AA}+$ & Aal & 2 \\
\hline $\mathrm{AA}$ & $\mathrm{AA}$ & $\mathrm{Aa} 2$ & 3 \\
\hline AA- & AA- & $\mathrm{Aa} 3$ & 4 \\
\hline \multicolumn{4}{|c|}{ High credit quality } \\
\hline $\mathrm{A}+$ & $\mathrm{A}+$ & A1 & 5 \\
\hline A & A & A2 & 6 \\
\hline A- & A- & A3 & 7 \\
\hline \multicolumn{4}{|c|}{ Good credit quality } \\
\hline $\mathrm{BBB}+$ & $\mathrm{BBB}+$ & Baal & 8 \\
\hline $\mathrm{BBB}$ & $\mathrm{BBB}$ & $\mathrm{Baa} 2$ & 9 \\
\hline BBB- & BBB- & Baa3 & 10 \\
\hline \multicolumn{4}{|c|}{ Speculative Grade } \\
\hline \multicolumn{4}{|c|}{ Speculative } \\
\hline $\mathrm{BB}+$ & $\mathrm{BB}+$ & $\mathrm{Ba} 1$ & 11 \\
\hline $\mathrm{BB}$ & $\mathrm{BB}$ & $\mathrm{Ba} 2$ & 12 \\
\hline BB- & BB- & $\mathrm{Ba} 3$ & 13 \\
\hline \multicolumn{4}{|c|}{ Highly speculative } \\
\hline $\mathrm{B}+$ & $\mathrm{B}+$ & B1 & 14 \\
\hline $\mathrm{B}$ & $\mathrm{B}$ & B2 & 15 \\
\hline B- & B- & B3 & 16 \\
\hline \multicolumn{4}{|c|}{ High default risk } \\
\hline $\mathrm{CCC}+$ & $\mathrm{CCC}+$ & Caal & 17 \\
\hline $\mathrm{CCC}$ & $\mathrm{CCC}$ & $\mathrm{Caa} 2$ & 18 \\
\hline CCC- & $\mathrm{CCC}-$ & $\mathrm{Caa} 3$ & 19 \\
\hline \multicolumn{4}{|c|}{ Very high default risk } \\
\hline $\mathrm{CC}$ & $\mathrm{CC}$ & $\mathrm{Ca}$ & 20 \\
\hline $\mathrm{C}$ & $\mathrm{C}$ & $\mathrm{C}$ & 21 \\
\hline
\end{tabular}

Source: Standard and Poor's, Moody's Investors Service, and FitchRatings.

${ }^{11}$ This conversion rule is the converse from the one mostly used in the literature (see Cantor and Packer 1996). Since our ultimate objective is to project ratings for poor countries; we want to leave open the rating spectrum downwards. 
Since a higher value of the dependent variable indicates a higher level of country risk, the correct sign for the coefficients of GNI per capita, GDP growth rate, reserve ratio, and rule of law is negative, whereas that of the coefficients of debt/exports ratio, growth volatility, and inflation is positive.

In what follows, we report results for four specifications of the model summarized in equation (1):

1. Dependent variable is rating as of end-2006; explanatory variables for 2005

2. Dated model: dependent variable as of end-2006, but if the rating was established in year $t$, then for that observation, use explanatory variables for year $t-1$.

3. Dated pooled model to test whether a first time rating by an agency systematically differs from its subsequent ratings

4. Dated model to test whether a first time rating by an agency is systematically affected by an existing rating from another agency

The motivation for these different specifications and results are discussed below. After specification 2, we also report results of model validation using within-sample prediction and, separately, cross comparison of a forecasted rating from one agency with an actual rating by another agency.

\section{Specification 1: Dependent variable as of end-2006; explanatory variables for} 2005

The first specification models ratings as of end-2006 as a function of (lagged) explanatory variables for 2005. We used ordinary least squares (OLS) for a cross-section of latest available ratings, following the literature on modeling sovereign credit ratings (Cantor and Packer 1996, Sutton 2005). However, some of the latest available ratings were established several years back, and have not changed in the meantime. ${ }^{12}$ In order to exclude these outdated ratings, we use ratings that were established between the beginning of 2003 and end-2006. This period covers most of the sample for the three rating agencies. Lagged values of the explanatory variables are used instead of contemporaneous values, in order to limit possible reverse causality from ratings to explanatory variables. For example, the current sovereign rating may plausibly influence the risk premium and willingness of investors to hold foreign-currency liabilities of the country. The results are reported in table 3.

All of the explanatory variables (except inflation) have the expected sign and are statistically significant at 5 percent across the three rating agencies. A higher GDP growth rate, a summary indicator of the performance of the economy, is associated with a better rating. Note that since ratings are on a negative numeric scale (with AAA equivalent to $1, \mathrm{AA}+$ to 2 and so

\footnotetext{
${ }^{12}$ For example, Cuba's (“Caal” rating from Moody’s was established in 1999.
} 
on), a negative relationship between an explanatory variable and the numeric rating implies that higher values of the explanatory variable are associated with better credit ratings. Similar is true for the GNI per capita, the reserve ratio, and the rule of law-higher values should be associated with lower numeric ratings and better letter rating. The coefficients associated with GNI per capita, the reserve ratio, and the rule of law variables have the expected negative signs. On the other hand, external debt (as a share of GDP) and the volatility of GDP growth are associated with a lower letter rating (and hence the positive sign). The coefficient of inflation is positive (as expected) but not significant. Given the cross-sectional nature of the regression, the $\mathrm{R}^{2}$ presented in table 3 is adjusted for the degrees of freedom.

Table 3: Regression results using 2005 explanatory variables for ratings in December 2006

\begin{tabular}{lccc}
\hline Dependent variable: Sovereign rating & S\&P & Moody's & Fitch \\
\hline GDP growth & $-0.50^{* * *}$ & $-0.43^{* * *}$ & $-0.29^{* * *}$ \\
Log of GNI per capita & $(0.07)$ & $(0.09)$ & $(0.09)$ \\
& $-1.63^{* * *}$ & $-2.17^{* * *}$ & $-1.49^{* * *}$ \\
Ratio of reserves to import and ST debt & $(0.24)$ & $(0.47)$ & $(0.22)$ \\
& $-4.23^{* * *}$ & $-4.41^{* * *}$ & $-3.76^{* * *}$ \\
Ratio of ext. debt to exports & $(1.03)$ & $(1.15)$ & $(0.98)$ \\
& $0.57^{* *}$ & $0.92^{* * *}$ & $0.82^{* * *}$ \\
GDP Volatility (5-yr std. dev.) & $(0.22)$ & $(0.31)$ & $(0.14)$ \\
& $0.63^{* * *}$ & $0.76^{* * *}$ & $0.49^{* * *}$ \\
Rule of law & $(0.10)$ & $(0.14)$ & $(0.10)$ \\
& $-1.77^{* * *}$ & $-2.15^{* * *}$ & $-1.95^{* * *}$ \\
Inflation & $(0.45)$ & $(0.71)$ & $(0.43)$ \\
& & 0.05 & \\
Observations & & $(0.08)$ & \\
Adjusted R-squared & & & 60 \\
\hline
\end{tabular}

* significant at 10\%; ** significant at 5\%; *** significant at 1\%. White robust standard errors are reported below coefficient estimates.

In trying to get a better fit, we excluded some outliers from these regressions (Belize and Kazakhstan in the Moody's regressions; Belize, Grenada, Madagascar and Uruguay in the S\&P regressions; and Lebanon and Iran in the Fitch regressions). The adjusted $\mathrm{R}^{2}$ was lower when these outliers were included (for example, 0.76 versus 0.82 in the Moody's regressions), but the signs and significance of the explanatory variables were unchanged. ${ }^{13}$

\footnotetext{
${ }^{13}$ Note that Belize was downgraded from CC to Selective Default by S\&P in December 2006 following the announcement of a debt restructuring; it was subsequently upgraded to B in February 2007 after the completion of the restructuring. Our predicted shadow rating for Belize is in the range of BB- to BB+. Similarly, Grenada had been rated as being in Selective Default in early 2005, and was upgraded back to B-
} 
It is plausible that some of the coefficients may be inconsistent and causality may be confounded in this regression due to potential presence of reverse causality from ratings to some of the explanatory variables. In other words, income per capita or external debt may itself depend on ratings. There are two reasons why this may not present serious difficulties for our purpose. First, this is a cross sectional study and we have deliberately used lagged data for all the independent variables, instead of contemporaneous values. Second, our purpose is to use the regression model as a best linear predictor of ratings, rather than for hypothesis-testing. In a cross section, this method gives reasonably good results.

\section{Specification 2: Dated model}

Dependent variable as of end-2006; but if the rating was established in year $t$, then use explanatory variables for year $t-1$

The regression model in the previous specification assumes that the latest available rating in end2006 reflects the prevailing view of the rating agency, i.e. that the macroeconomic and political situation has not improved (deteriorated) sufficiently to warrant an upgrade (downgrade) between the date the rating was established and end-2006. However, a rating established a few years back may not have changed for other reasons - a likely one being that the country may not have requested or paid for a rating. Since it is not possible to distinguish between the two with the available information, we use what we believe to be a more robust specification. We use lagged "dated" explanatory variables relative to the year in which the latest available rating was established. ${ }^{14}$ For example, the latest available rating by S\&P for Estonia is for 2004, we use 2003 control variables. For the latest ratings that were established in 2006, we continue to use the 2005 control variables. As before, we exclude outliers to improve the fit of the prediction model. The results are reported in table 4.

The signs of the explanatory variables in table 4 are in the expected direction, and are significant at the 10 percent level or better. The additional variable that is now significant is inflation, with higher inflation being correlated with worse ratings. All these variables together explain about 80 percent of the variation in ratings for the dated regression sample. With such high explanatory power, it is not surprising that the predicted ratings are the same or close to the actual ratings for a large number of countries in the sample (see annex table 1). Below we use this as the benchmark model for predicting ratings for unrated countries.

by the end of 2006. Another outlier is Lebanon, where the rating is affected by a high level of debt, but does not adequately account for large remittances from the Lebanese diaspora (World Bank 2005a, chapter $4)$.

${ }^{14}$ The latest rating contains the most valid information about the macroeconomic and political fundamentals of a country in the year it was established. Therefore, the information content in the dated explanatory variable would be the highest. 
Table 4: Regression results: using dated explanatory variables for latest ratings as of December 2006

\begin{tabular}{lccc}
\hline Dependent variable: Sovereign rating & S\&P & Moody's & Fitch \\
\hline GDP growth & $-0.47^{* * *}$ & -0.03 & $-0.19^{*}$ \\
& $(0.08)$ & $(0.09)$ & $(0.10)$ \\
Log of GNI per capita & $-1.41^{* * *}$ & $-0.69^{*}$ & $-1.34^{* * *}$ \\
& $(0.29)$ & $(0.35)$ & $(0.26)$ \\
Ratio of reserves to import and ST debt & $-3.41^{* * *}$ & $-2.21^{* * *}$ & $-4.16^{* * *}$ \\
& $(0.87)$ & $(0.65)$ & $(0.92)$ \\
Ratio of ext. debt to exports & $0.68^{* * *}$ & $1.68^{* * *}$ & $0.77^{* * *}$ \\
& $(0.24)$ & $(0.25)$ & $(0.23)$ \\
GDP Volatility (5-yr std. dev.) & $0.37^{* * *}$ & 0.06 & $0.38^{* * *}$ \\
& $(0.10)$ & $(0.12)$ & $(0.09)$ \\
Rule of law & & & \\
Inflation & $-2.60^{* * *}$ & $-2.68^{* * *}$ & $-2.20^{* * *}$ \\
Observations & $(0.43)$ & $(0.60)$ & $(0.41)$ \\
Adjusted R-squared & & $0.17^{* * *}$ & \\
\hline
\end{tabular}

* significant at $10 \% ; * *$ significant at $5 \%$; *** significant at $1 \%$. White robust standard errors are reported below coefficient estimates.

\section{Model validation using within-sample predictions}

Our next step is to use the fitted model to predict the value of the dependent variable. Note that we have three models, one for each agency. Before proceeding to prediction, we check the validity of the model using a variety of methods. Model validation involves using the available sample to verify that the model would give reasonable predictions. Using a model for the latest rating as of end-2005, we predict ratings for 2006 and compare these with the actual ratings assigned in 2006. This within-sample forecasting allows us to compare the actual ratings with the ratings predicted by the model. The regression results for ratings as of end-2005 are qualitatively very similar to the results reported in table 4 above, confirming that the model is indeed very stable. $^{15}$

\footnotetext{
${ }^{15}$ These results are available from the authors upon request. We do not report these results here as they may make the article too long.
} 
Figure 6: Comparing actual S\&P ratings established in 2006 with predicted ratings

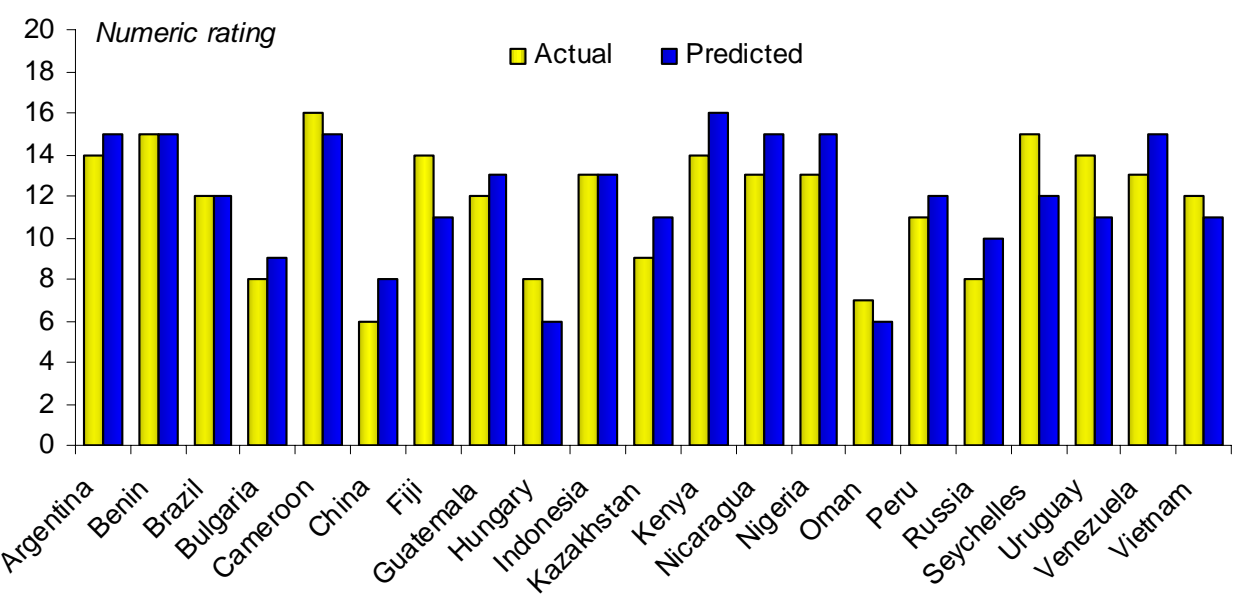

Source: S\&P and authors' calculations. A higher number indicates higher risk and lower letter rating. See table 2 for conversion from letter to numeric scale.

Figure 6 compares the ratings established in 2006 by Standard and Poor's with the predicted ratings using explanatory variables for 2005. The predicted ratings for 2006 are within one to two notches of the actual rating for most of the countries that have a rating. The small variation around actual ratings can be attributed to two factors. First, several of these developing countries have not been rated for some time and were therefore not part of the regression sample (the latest available rating for these was established before 2003). Second, the model captures economic and governance variables and the average relationship of these variables with the sovereign rating. There are events that the explanatory variables in the model may not adequately capture, a military coup and nationalization of some crucial export sector such as oil, for example. Based on these within-sample forecasts, we conclude that the benchmark prediction model (Specification 2) is reasonably good at predicting the sovereign rating for most developing countries.

\section{Model validation using cross comparison between agency ratings}

To validate our models, we also exploit the fact that several countries are rated by one of the agencies but not by the others. In such cases, we can compare the predicted rating from one of the rating models with the actual rating by another agency. For example, Lesotho is rated BB- by Fitch, but it is not rated by S\&P and Moody's. The predicted rating for Lesotho, using the model estimated for S\&P ratings, is also found to be BB-. Similarly, Uganda is rated B by Fitch, within one notch of the predicted rating of B- using the S\&P model. Figure 7 compares sovereign ratings established by Fitch in 2005-06 with the predicted rating from Moody's and S\&P for countries that were not rated by one or the other agency by end-2006. The average predicted rating from the 
Moody's and S\&P models is used when both actual ratings are unavailable. The model seems to perform reasonably well in terms of emulating the actual rating of countries rated by Fitch. ${ }^{16}$

Figure 7: Comparing actual Fitch ratings at end-2006 with predicted ratings from other two agencies

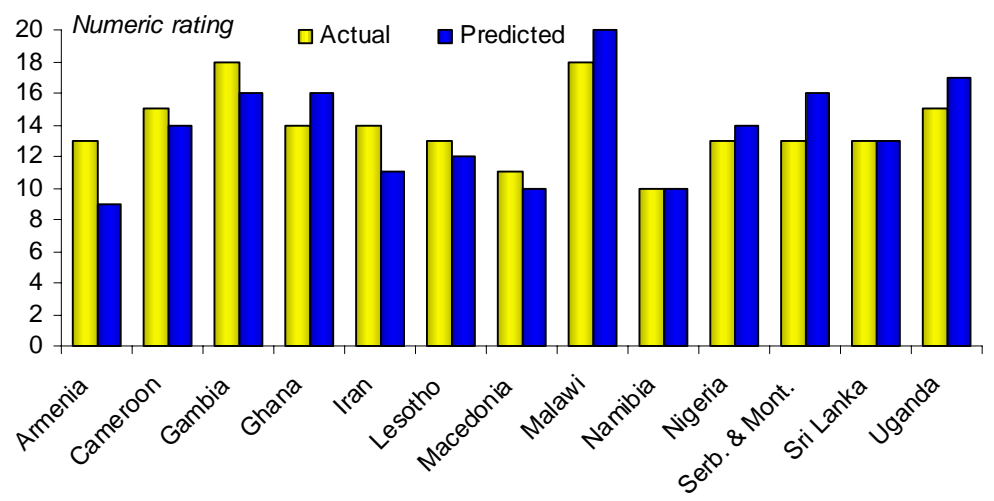

Source: S\&P, Moody's, Fitch Ratings, and authors' calculations. A higher number indicates higher risk and lower letter rating. See table 2 for conversion from letter to numeric scale.

\section{Modeling new ratings and the very first rating}

\section{Specification 3: Dated pooled model to test whether a first time rating by an agency systematically differs from its subsequent ratings}

We carry out two final regressions for sovereign ratings. Our interest is in what a new rating for a country would look like if there is no existing rating for all three agencies, and when there is an existing rating by one agency. To test whether the sovereign rating varies systematically between a new rating by an agency and a subsequent rating by the same agency, we use a regression model similar to the dated model specification for the entire pooled sample of all available ratings, with a dummy for the very first rating by the agency as an additional explanatory variable. We use the International Country Risk Guide (ICRG) composite index instead of the Rule of Law as an explanatory variable since the latter was not available for the period prior to 1996. The results are reported in table 5.

The explanatory variables have the expected signs and are statistically significant. The coefficient for the very first rating is negative in all three cases, but significant only the case of Fitch. The first rating tends to be somewhat more optimistic than subsequent ratings, perhaps because countries choose to get rated when they are doing relatively better. It may also imply that rating agencies oblige new customers with a better first rating.

\footnotetext{
${ }^{16}$ Across-agency comparisons for S\&P and Moody’s ratings are qualitatively similar.
} 
Table 5: Pooled regression results: on new ratings

\begin{tabular}{lccc}
\hline Dependent variable: Sovereign rating & S\&P & Moody's & Fitch \\
\hline GDP growth (3-yr MA \%) & $-0.23^{* * *}$ & $-0.29 * * *$ & $-0.08 * *$ \\
Log of GNI per capita & $-0.66^{* * *}$ & $-0.77^{* * *}$ & $-0.51^{* * *}$ \\
ICRG composite index & $-.20^{* * *}$ & $-0.14^{* * *}$ & $-0.18^{* *}$ \\
Ratio of reserves to import and ST debt & $-1.01 * * *$ & $-0.64 * * *$ & $-1.67 * * *$ \\
Ratio of ext. debt to exports & $0.66^{* * *}$ & $0.67 * * *$ & $0.96 * * *$ \\
GDP Volatility (5 yr Std. Dev.) & $0.17 * * *$ & $0.18^{* * *}$ & $0.29 * * *$ \\
Dummy for first rating & -0.39 & -0.19 & $-1.55^{* * *}$ \\
& & & 374 \\
Observations & 520 & 514 & 0.62 \\
\hline
\end{tabular}

* significant at $10 \% ; * *$ significant at $5 \%$;** significant at $1 \%$. White robust standard errors are suppressed.

Table 6: Regression results: on very first rating

\begin{tabular}{lccc}
\hline Dependent variable: First sovereign rating & S\&P & Moody’s & Fitch \\
\hline GDP growth (3-yr MA \%) & $-0.85^{*}$ & -0.15 & $0.15^{* *}$ \\
Log of GNI per capita & -0.15 & 0.38 & 0.39 \\
Rule of law & 0.48 & -0.06 & $-0.08^{*}$ \\
Ratio of reserves to import and ST debt & $-0.56^{* *}$ & 0.2 & $-1.7^{* *}$ \\
Ratio of ext. debt to exports & 0.19 & 0.28 & 0.06 \\
GDP Volatility (5-yr Std. Dev.) & 0.08 & $-0.16^{*}$ & 0.01 \\
Existing rating (by another agency) & $0.76^{* * *}$ & $0.91^{* * *}$ & $0.87^{* * *}$ \\
& & & \\
Observations & 36 & 28 & 38 \\
Adjusted R-squared & 0.89 & 0.9 & 0.92 \\
\hline
\end{tabular}

* significant at $10 \% ; * *$ significant at $5 \%$;** significant at $1 \%$. White robust standard errors are suppressed. 
Specification 4: Dated model to test whether a first time rating by an agency is systematically affected by an existing rating from another agency

The final specification considers the case when there is an existing rating by another agency when a rating agency rates a country for the very first time. We use a regression model for the very first rating similar to the dated specification, with the existing rating by another agency as an additional explanatory variable. The results reported in table 6 show that the first rating assigned by an agency is highly influenced by the existing rating assigned by its competitors. Indeed, this factor appears more important that the standard set of explanatory variables used in our models (which presumably are already reflected in the existing rating, according to the results of specification 3 above). These results again underscore that ratings by the three major agencies tend to be highly correlated.

\section{Predictions for unrated developing countries}

We use the benchmark model in table 4 to predict ratings for the unrated developing countries. The range of predicted ratings generated by the three separate models is reported in table 7.

From these results, many countries appear to be more creditworthy than previously believed. It is rather striking to see that the predicted ratings for the unrated countries do not all lie at the bottom end of the rating spectrum, but are spread over a wide range (figure 8). Of the 55 unrated countries for which we were able to generate predicted ratings, only 14 are likely to be rated $\mathrm{CC}$ or lower; 8 countries are likely to be above investment grade, 18 are likely to be in the $\mathrm{B}$ to $\mathrm{BB}$ category, and 15 in the CCC category. ${ }^{17}$ The countries just below the investment grade but at or above $\mathrm{CCC}$ are comparable to many emerging market countries with regular market access. For example, the shadow rating for $\mathrm{S} \& \mathrm{P}$ for Bangladesh in our analysis is a range from $\mathrm{B}-$ to $\mathrm{B}$, which puts it in a similar bracket as emerging market countries such as Bolivia and Uruguay. There several other unrated developing countries (e.g. Belarus, Cambodia, Chad, Dominica, Equatorial Guinea, Tajikistan, and Yemen) with shadow ratings in the B category or above.

Even though the model-based shadow ratings may not capture all possible elements of country risk, a natural question that arises is: what variables included in the model explain what percentage of a country's predicted rating? As an illustration, annex table 2 shows the contribution of each explanatory variable to the predicted rating using the benchmark model for Standard and Poor's (table 4). The predictions are based on the latest information as of end-2005, in order to ensure the broadest possible sample.

\footnotetext{
${ }^{17}$ This distribution is based on the lowest of the predicted rating from the three rating models. If instead we used the highest rating, the ratings would be even more striking: as many as 13 countries would be above investment grade, 7 would be BB, 15 would be B, and 11 would be CCC.
} 
Figure 8: Distribution of predicted ratings

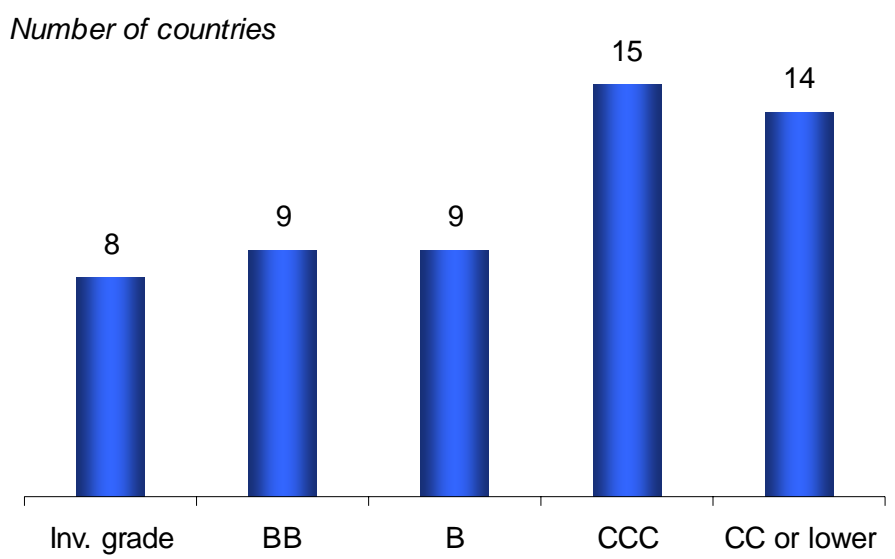

Source: Authors' calculations. The distribution is based on the lowest predicted rating in table 7.

We focus first on the countries with predicted S\&P ratings in the investment grade category. Some of their success is due to factors such as past wealth and high oil prices that may not be sustainable over the long-run. For example, Kiribati's AAA rating is mostly due to extraordinarily high reserves accumulated from a trust fund, the Revenue Equalization Reserve Fund of some $\$ 600$ million established from earlier phosphate mining revenues (Graham 2005). Libya, Algeria, Equatorial Guinea and Syria are all oil exporters, and consequently have very strong foreign exchange reserve positions and low levels of external debt relative to exports. Further, Algeria, Equatorial Guinea and Libya's oil wealth puts them in the middle or uppermiddle income categories among developing countries. Others, such as the island nations St. Kitts, St. Vincent and St. Lucia have high ratings primarily due to their high incomes from offshore banking and tourism. Bhutan, a lower-middle income country, has an investment grade rating due to a strong reserve position, above-average growth and good governance (a high ruleof-law indicator) although with a debt ratio close to the average for unrated countries.

At the lower end of the spectrum are countries such as Sao Tome, Eritrea, Central African Republic, Zimbabwe, Liberia and Burundi, whose predicted S\&P numeric ratings puts them "out-of-range" on the S\&P letter rating scale. All of these countries are poor, with per capita gross national income (GNI) ranging from $\$ 130$ to $\$ 340$ in 2005, with high debt ratios, poor governance and low (or negative) GDP growth. These negative factors contribute to very low shadow ratings.

Countries in the "middle" that have a sub-investment grade shadow rating for S\&P but are at least in the B category (from Vanuatu down to Lao PDR) are usually characterized by higher GDP growth, lower debt ratio, lower GDP volatility and better governance compared to the sample of all unrated countries. These countries are not uniformly good performers in all respects. For example, several (Tonga, Samoa, Tanzania, Mauritania, Lao PDR) had significantly higher external debt ratios than the average in 2005. However, some of their positive attributes ameliorates this to some extent - high GDP growth in Tanzania, Mauritania and Lao PDR; relatively high GNI per capita and good governance in Tonga and Samoa. Similarly, Bangladesh 
had low external reserves relative to imports and short-term debt in 2005 and relatively poor governance, but did well in terms of growth and macroeconomic stability.

The predicted ratings of four countries are shown as "out of range" in table 7, to indicate that they are riskier than "C" rating. These countries are conventionally perceived as extremely risky. Indeed, all these countries are considered at high risk of debt distress ("red light" countries) by IDA (2006b).${ }^{18}$ However, are they below "default" status? Empirically, it is not clear what numeric value one might assign to default. We have, therefore, excluded default cases in our regression analysis.

We have used outstanding external debt instead of the net present value (NPV) of external debt in our regression analysis. In the case of countries that have received debt relief under HIPC or MDRI, the NPV of future repayments may be lower than the stock of outstanding debt. Such countries may be more creditworthy than predicted by our model. ${ }^{19}$ The rating agencies have been slow to upgrade such countries taking the view that debt relief may be a oneoff event with transitory effects.

It is worth reiterating that model-based predictions reported here can only be a rough guide, but not a substitute for rigorous and forward-looking analysis by seasoned analysts. First, we are forced to use past data, rather than forecasts for the explanatory variables, in order to include the largest possible sample of unrated countries. Second, the shadow ratings may not capture political factors that are not fully captured in the Rule of Law index, e.g. war, civil conflict. Budget deficit, which has been cited in the literature as an important explanatory variable was not used due to lack of consistent and comparable information, for instance arising form varying definitions (e.g. central government versus general government). Since the objective was to generate predictions for the broadest sample of countries possible, only variables that were available on a comparable basis for the largest possible set of countries were used. In this exercise, we do not explicitly account for why countries do not get rated. This is an area of future research. Even with these important caveats, the above results show that unrated countries are not necessarily at the bottom of the ratings spectrum; that many of them are more creditworthy than previously believed.

\section{Summary of results and policy implications}

Sovereign ratings from major rating agencies affect the access of sovereign and subsovereign entities to international capital markets. In addition to raising debt in capital markets, ratings are useful for the Basle II capital-adequacy norms for commercial banks. FDI and

\footnotetext{
${ }^{18}$ There are 40 unrated IDA countries for which we predicted shadow ratings. Of these, countries with shadow rating below CCC- are classified as at high risk of debt distress ("red light") by IDA methodology which is based on Kraay and Nehru (2006).

${ }^{19}$ The "free-rider" problem created by debt relief may be less of a concern when outstanding debt is used instead of NPV.
} 
portfolio investors typically use sovereign ratings to gain an aggregate view of the risk of investing in a particular country. For a developing country, the sovereign rating can provide a benchmark for the cost and size of potential debt issuance. Even aid allocations from multilateral agencies (e.g. IDA aid allocations) and bilateral donors (e.g. the U.S Millennium Challenge Account) are affected by sovereign creditworthiness criteria.

In this paper, we have tried to develop an econometric model for explaining sovereign ratings assigned to developing countries by the three major rating agencies. Our ultimate purpose is to "predict" shadow ratings for the 70 or so unrated countries.

The main findings of this paper can be summarized as follows:

- The model seems works very well in explaining sovereign credit ratings. Within-sample forecasts (using the ratings sample until 2005 to predict 2006 ratings, for example) are usually within one to two notches of the actual sovereign ratings for rated developing countries.

- The ratings by the three agencies are highly correlated. The bivariate correlation ranges from 0.97-0.99.

- Our model-based rating predictions show that many unrated countries are likely to have higher ratings than currently believed, many in a similar range as the so-called emerging markets. This finding is robust to a variety of specifications. This contradicts the conventional wisdom that countries that lack a sovereign rating are at the bottom of the ratings spectrum.

- Spreads rise exponentially as the credit rating deteriorates, registering a sharp rise at the investment grade threshold. For a $\$ 100$ million, 7-year bond in 2005, the launch spread would rise from 55 basis points for a 'BBB-' rating, then rise sharply to 146 basis points as rating falls below the investment-grade threshold to ' $\mathrm{BB}+$ ' before reaching a high of 577 basis points for a ' $\mathrm{CCC}+$ ' rating. The large shift of 91 basis points at the investment grade threshold likely reflects the limitations or regulations that prevent institutional investors from buying sub-investment grade. An implication is that if a country or borrowing entity were to obtain an investment grade rating, the investor base widens considerably.

The shadow rating for a country can provide a sense of where the country would lie on the credit rating spectrum if it were to be rated. The model-based shadow ratings can provide a benchmark for evaluating unrated countries, as well as rated countries that have not been rated for some time and might have improved sufficiently in the meantime to deserve an upgrade (or downgrade in some cases).

As shown in box 1, for developing countries with sovereign ratings that are belowinvestment grade, the sovereign ceiling often acts as a binding constraint, which limits market access and keeps borrowing costs high for sub-sovereign entities located in these countries. Preliminary results indicate that, after controlling for global liquidity conditions and country and 
firm-specific factors, a developing country's sovereign credit rating explains some 64 percent of the variation in ratings of sub-sovereign entities located in its jurisdiction.

Poor countries can use a variety of structuring mechanisms to raise their creditworthiness, pierce the sovereign ceiling and establish market access. The spread saving from improving ratings from $\mathrm{B}$ to $\mathrm{BBB}$ would be in the range of $320-450$ basis points. The knowledge of this relationship can be helpful for bilateral and multilateral donors interested in setting up guarantees and other financial structures to reduce project risks and mobilize private financing. According to Gelb, Ramachandran and Turner (2006), World Bank and IDA guarantees of \$2.9 billion have been able to catalyze private capital of $\$ 12$ billion for large infrastructure projects. ${ }^{20}$ An official grant can be used as a first-loss reserve, for example, which can substantially improve the credit rating of the project.

A financing structure that raises the rating of a project to investment grade can attract a larger pool of investors (e.g. pension funds) facing limitations on buying non-investment grade securities. In poor countries that have recently received debt relief and where there are concerns regarding nonconcessional borrowing, these mechanisms can be used mainly for private-sector development projects. By lowering borrowing costs and lengthening maturities, these structures can in turn increase net resource flows to poor countries. These mechanisms can complement existing efforts to improve aid effectiveness (Gelb and Sundberg 2006).

Similarly, foreign currency inflows (of remittances, tourism revenue, export receivables) can be leveraged for improving foreign currency ratings. Any improvement in sovereign rating is likely to translate into an improvement in the rating of sub-sovereign borrowers whose foreign currency borrowing is typically subject to the sovereign rating ceiling. Future foreign currency inflows can then used as collateral by private sector entities, banks and other financial intermediaries to improve their own ratings, allowing them to pierce the sovereign rating ceiling, and issue bonds at lower interest spreads and longer tenor (Ketkar and Ratha 2005). Several banks in developing countries — ranging from Brazil, Mexico and Turkey, to Egypt, Jamaica and Kazakhstan in more recent years - have been able to raise cheaper and longer-term financing from international capital markets using securitization of future remittance flows (Ratha 2006).

That many unrated poor countries may be more creditworthy than currently believed provides hope for a private sector-to-private sector alternative for financing poverty reduction and other Millennium Development Goals in these countries. Future research should examine how sovereign ratings influence the ratings of sub-sovereign entities; what kind of financing structures can help poor countries access international capital markets; and what are the regulatory preconditions necessary for such financial structures to succeed in poor countries.

\footnotetext{
${ }^{20}$ See Klein (1997) and World Bank (2005b) for the key features of World Bank partial risk and credit guarantees. Similar credit enhancements using official aid have been used to mobilize private resources for a diverse range of programs, e.g. Charter Schools in the United States, with leverage ratios as high as 10-15 times the grant (See www.ed.gov/programs/charterfacilities/2005awards).
} 


\section{References}

Bhatia, Ashok V. 2002. "Sovereign Credit Ratings Methodology: An Evaluation.” Working Paper 02/170. International Monetary Fund, Washington, DC.

Beers, David, and Marie Cavanaugh. 2005. "Sovereign Credit Ratings: A Primer.” RatingsDirect. Standard and Poors. September.

Berg, Andrew, and Jeffrey Sachs. 1988. "The Debt Crisis: Structural Explanations of Country Performance". Journal of Development Economics 29: 271-306.

Calvo, Guillermo A., and Carmen M. Reinhart. 1999. "When Capital Inflows Come to a Sudden Stop: Consequences and Policy Options.” Mimeo. University of Maryland.

Cantor Richard, and Frank Packer. 1995. "Sovereign Credit Ratings." Current Issues in Economics and Finance. Federal Reserve Bank of New York. June.

Cantor, Richard, and Frank Packer. 1996. "Determinants and Impact of Sovereign Credit Ratings.” Economic Policy Review 2. Federal Reserve Bank of New York. October.

Claessens, Stijn, and Geert Embrechts. 2002. "Basel II, Sovereign Ratings and Transfer Risk: External versus Internal Ratings." Presented at the conference Basel II: An Economic Assessment, Bank for International Settlements, Basel, 17-18 May 2002.

Eichengreen, Barry, and Ashoka Mody. 2000. "What Explains Changing Spreads on Emerging Market Debt?" In Capital Flows and The Emerging Economies: Theories, Evidence, and Controversies, ed. Sebastian Edwards. Chicago: University of Chicago Press.

Hausmann, Ricardo, and Eduardo Fernández-Arias. 2001. "Foreign Direct Investment: Good Cholesterol?" In Foreign Direct Investment Versus Other Flows to Latin America, ed. Jorge Braga de Macedo and Enrique V. Iglesias. Organisation for Economic Cooperation and Development, Paris.

Ferri, Giovanni, Li-Gang Liu and Giovanni Majnoni. 2001. “The Role of Rating Agency Assessments in Less Developed Countries: Impact of the Proposed Basel Guidelines." Journal of Banking and Finance 25: 115-125.

Ferri, Giovanni. 2003. "How Do Global Credit-Rating Agencies Rate Firms from Developing Countries." Asian Economic Papers 2(3): 30-56.

Ferri, Giovanni, Li-Gang Liu and Joseph E. Stiglitz. 1999. “Are Credit Ratings Pro-cyclical? Evidence from East Asian Countries.” Economic Notes 28(3): 335-355.

FitchRatings. 1998. "Sovereign Rating Methodology.” Bureau of African Affairs, U.S Department of State. www.state.gov.

Gelb, Alan, Vijaya Ramachandran and Ginger Turner. 2006. "Stimulating Growth and Investment in Africa - from Macro to Micro Reforms." Paper prepared for AfDB-AERC Conference, Tunis, November 22-24, 2006. www.afdb.org. 
Gelb, Alan and Mark Sundberg. 2006. "Making Aid Work." Finance and Development 43(4). International Monetary Fund, Washington, DC. December.

Graham, Benjamin. 2005. "Trust Funds in the Pacific: Their Role and Future.” Pacific Studies Series. Asian Development Bank, Manila.

International Development Association. 2006a. "Assessing Implementation of IDA14 Grants Framework." World Bank, Washington, DC. www.worldbank.org/ida.

International Development Association. 2006b. "Debt Dynamics and Financing Terms: A Forward-Looking Approach to IDA Grant Eligibility.” World Bank, Washington, DC. www.worldbank.org/ida.

Kamin, Steven B., and Karsten von Kleist. 1999. "The Evolution and Determinants of Emerging Market Credit Market Credit Spreads in the 1990s." Working Paper 68. Bank for International Settlements, Basel.

Kaminsky, Graciela and Sergio Schmukler. 2002. "Emerging Market Instability: Do Sovereign Ratings Affect Country Risk and Stock Returns." World Bank Economic Review 16(2): 171-190.

Kaufmann, Daniel, Aart Kraay, and Massimo Mastruzzi. 2006. "Governance Matters V: Governance Indicators for 1996-2005.” World Bank Institute, Washington, DC. September.

Ketkar, Suhas, and Dilip Ratha. 2005. "Recent Advances in Future-Flow Securitization." The Financier 11/12. December.

Klein, Michael. 1997. "Managing Guarantee Programs in Support of Infrastructure Investment." Policy Research Working Paper 1812. World Bank, Washington, DC.

Kraay, Aart, and Vikram Nehru. 2006. "When Is External Debt Sustainable?” World Bank Economic Review 20(3): 341-365.

Lee, Suk Hun. 1993. "Are the Credit Ratings Assigned by Bankers Based on the Willingness of LDC Borrowers to Repay?” Journal of Development Economics 40: 349-59.

Lehmann, Alexander. 2004. "Sovereign Credit Ratings and Private Capital Flows to Low-Income Countries." African Development Review 16(2).

Loungani, Prakash, and Assaf Razin. 2001. "How Beneficial Is Foreign Direct Investment for Developing Countries?" Finance and Development 38(2). International Monetary Fund, Washington, DC.

Manasse, Paolo, Nouriel Roubini, and Axel Schimmelpfenning. 2003. "Predicting Sovereign Debt Crises," Working Paper 03/221. International Monetary Fund, Washington, DC.

Mora, Nada. 2006. “Sovereign Credit Ratings: Guilty beyond Reasonable Doubt?” Journal of Banking and Finance 30(7): 2041-2062. 
Moody's. 2004. "Measuring the Quality and Consistency of Corporate Ratings across Regions." Moody's Investors Services, New York. November. www.moodyskmv.com.

Panizza, Ugo, Barry Eichengreen and Ricardo Hausmann. 2005. "The Mystery of Original Sin." In Other People's Money: Debt Denomination and Financial Instability in EmergingMarket Economies, ed. Barry Eichengreen and Ricardo Hausmann. Chicago: University of Chicago Press.

Ratha, Dilip. 2006. "Leveraging Remittances for International Capital Market Access." Mimeo. Development Prospects Group. World Bank, Washington, DC. www.worldbank.org/prospects/migrationandremittances.

Reinhart, Carmen M. 2002a. "Sovereign Credit Ratings Before and After Financial Crises." In Ratings, Rating Agencies and the Global Financial System, ed. Richard Levich, Carmen M. Reinhart, and Giovanni Majnoni. New York: Kluwer Academic Press.

Reinhart, Carmen M. 2002b. "Credit Ratings, Default, and Financial Crises: Evidence from Emerging Markets.” World Bank Economic Review 16(2): 151-170.

Reinhart, Carmen M., Kenneth S. Rogoff and Miguel A. Savastano. 2003. "Debt Intolerance." Brookings Papers on Economic Activity 1: 1-74.

Rowland, Peter and Jose L. Torres. 2004. "Determinants of Spread and Creditworthiness for Emerging Market Sovereign Debt: A Panel Data Study.” Mimeo. Banco de la República, Bogota.

Rowland, Peter. 2005. "Determinants of Spread, Credit Ratings and Creditworthiness for Emerging Market Sovereign Debt: A Follow-Up Study Using Pooled Data Analysis.” Mimeo. Banco de la República, Bogota.

Standard and Poors. 2006. Sovereign Ratings in Africa. Standard and Poors, New York.

Sutton, Gregory. 2005. "Potentially Endogenous Borrowing and Developing Country Sovereign Credit Ratings.” Financial Stability Institute Occasional Paper 5. Bank for International Settlements, Basel.

Truglia, Vincent, and Pierre Cailleteau. 2006. “A Guide to Moody’s Sovereign Ratings.” Special Comment. Moody's Investors Service, New York. August.

World Bank. 2005a. Global Economic Prospects 2006: Economic Implications of Remittances and Migration. World Bank, Washington, DC.

World Bank. 2005b. "The World Bank Guarantees: Overview and Key Features.” Mimeo. World Bank: Washington, DC. 
Table 7: Predicted ratings for unrated developing countries*

\begin{tabular}{|c|c|c|}
\hline Country & Predicted rating range & Rated countries in the same range \\
\hline Albania & $\mathrm{BB}$ to $\mathrm{BB}+$ & Brazil; Colombia; El Salvador \\
\hline Algeria & A to $\mathrm{AA}$ & Chile; China; Estonia \\
\hline Angola & $\mathrm{CCC}+$ to $\mathrm{B}+$ & Uruguay; Argentina; Ecuador \\
\hline Bangladesh & $\mathrm{B}$ - to $\mathrm{B}$ & Jamaica; Dominican Republic; Bolivia \\
\hline Belarus & $\mathrm{BB}-$ to $\mathrm{BB}+$ & El Salvador; Philippines; Indonesia \\
\hline Bhutan & $\mathrm{BBB}-$ to $\mathrm{BBB}+$ & Poland; South Africa; Thailand \\
\hline Burundi & $* *$ & \\
\hline Cambodia & $\mathrm{B}+$ & Pakistan; Argentina; Georgia \\
\hline Central African Rep. & C or lower & \\
\hline Chad & $\mathrm{B}-$ to $\mathrm{B}+$ & Uruguay; Argentina; Bolivia \\
\hline Comoros & $\mathrm{CC}$ to $\mathrm{CCC}+$ & Ecuador; Belize \\
\hline Congo, Dem. Rep. & C or lower & \\
\hline Congo, Rep. & $\mathrm{CCC}+$ to $\mathrm{B}-$ & Bolivia; Paraguay; Cameroon \\
\hline Cote d'Ivoire & $\mathrm{CCC}-$ to $\mathrm{CCC}+$ & Ecuador \\
\hline Djibouti & $\mathrm{B}$ to $\mathrm{B}+$ & Uruguay; Argentina; Georgia \\
\hline Dominica & $\mathrm{BB}+$ to $\mathrm{BBB}$ & Mexico; Romania; India; \\
\hline Equatorial Guinea & $\mathrm{BB}+$ to $\mathrm{BBB}-$ & India; El Salvador; Peru \\
\hline Eritrea & $* *$ & \\
\hline Ethiopia & CCC- & \\
\hline Gabon & $\mathrm{BB}+$ to $\mathrm{BBB}$ & Mexico; Romania; Peru \\
\hline Guinea & CCC or lower & \\
\hline Guinea-Bissau & $\mathrm{C}$ to $\mathrm{CC}$ & \\
\hline Guyana & $\mathrm{CCC}+$ to $\mathrm{B}$ & Dominican Republic; Bolivia; Ecuador \\
\hline Haiti & $\mathrm{C}$ to $\mathrm{CCC}-$ & \\
\hline Kiribati & AAA & \\
\hline Kyrgyz Republic & $\mathrm{CCC}+$ to $\mathrm{B}-$ & Bolivia; Lebanon; Paraguay \\
\hline Lao PDR & $\mathrm{CCC}-$ to $\mathrm{B}-$ & Bolivia; Paraguay; Ecuador \\
\hline Liberia & $* *$ & \\
\hline Libya & AA to AAA & \\
\hline Maldives & $\mathrm{BB}+$ to $\mathrm{BBB}$ & Mexico; Croatia; India \\
\hline Marshall Islands & $\mathrm{B}-$ to $\mathrm{B}+$ & Pakistan; Uruguay; Bolivia \\
\hline Mauritania & $\mathrm{CCC}$ to $\mathrm{B}$ & Dominican Republic; Bolivia; Paraguay \\
\hline Myanmar & $\mathrm{CCC}-$ & \\
\hline Nepal & $\mathrm{CCC}+$ to $\mathrm{B}$ & Dominican Republic; Bolivia; Paraguay \\
\hline
\end{tabular}




\begin{tabular}{|c|c|c|}
\hline Country & Predicted rating range & Rated countries in the same range \\
\hline Niger & $\mathrm{CCC}$ - to $\mathrm{CCC}$ & \\
\hline Rwanda & $\mathrm{CC}$ or lower & \\
\hline Samoa & $\mathrm{CCC}+$ to $\mathrm{BB}-$ & Turkey; Philippines; Ukraine \\
\hline Sao Tome and Principe & & \\
\hline Sierra Leone & CCC- & \\
\hline Solomon Islands & $\mathrm{B}-$ to $\mathrm{B}+$ & Pakistan; Uruguay; Sri Lanka \\
\hline St. Kitts and Nevis & $\mathrm{BBB}+$ to $\mathrm{A}-$ & Czech Republic; Malaysia; Thailand \\
\hline St. Lucia & $\mathrm{BBB}$ to $\mathrm{BBB}+$ & Thailand; South Africa; Mexico \\
\hline $\begin{array}{l}\text { St. Vincent and the } \\
\text { Grenadines }\end{array}$ & $\mathrm{BBB}$ to $\mathrm{BBB}+$ & Thailand; South Africa; Mexico \\
\hline Sudan & $\mathrm{CCC}$ or lower & \\
\hline Swaziland & $\mathrm{BB}-$ to $\mathrm{BB}$ & Brazil; Colombia; Turkey \\
\hline Syrian Arab Republic & $\mathrm{A}-$ to $\mathrm{A}+$ & Chile; China, Czech Republic \\
\hline Tajikistan & $\mathrm{B}$ to $\mathrm{B}+$ & Uruguay; Argentina; Georgia \\
\hline Tanzania & $\mathrm{CCC}+$ to $\mathrm{B}+$ & Pakistan; Argentina; Bolivia \\
\hline Togo & $\mathrm{CCC}$ to $\mathrm{CCC}+$ & Ecuador \\
\hline Tonga & $\mathrm{B}+$ to $\mathrm{BB}+$ & Brazil; Colombia; Indonesia \\
\hline Uzbekistan & $\mathrm{B}$ to $\mathrm{BB}-$ & Philippines; Indonesia; Argentina \\
\hline Vanuatu & $\mathrm{BB}+$ to $\mathrm{BBB}+$ & Thailand; Russia; Peru \\
\hline Yemen, Rep. & BB- to $\mathrm{BB}$ & Costa Rica; Guatemala; Colombia \\
\hline Zambia & $\mathrm{CCC}+$ or lower & Ecuador \\
\hline Zimbabwe & $\mathrm{CC}$ or lower & \\
\hline
\end{tabular}

* These model-based ratings should be treated as indicative; they are clearly not a substitute for the broader and deeper analysis, and qualitative judgment, employed by experienced rating analysts. The predicted ratings range is based on predictions for the benchmark models for S\&P, Moody's and Fitch. Dated explanatory variables were used for predicting ratings for 2006. Note that these shadow ratings are not predictions for future rating changes. For that one would need forecasts for the explanatory variables.

** When the predicted rating was above 21 in the numeric scale, we classified it as out of range.

Source: Authors'calculations. 
Annex table 1: Actual and predicted ratings for rated developing countries*

\begin{tabular}{|c|c|c|c|c|}
\hline \multirow[t]{2}{*}{ Country } & \multicolumn{3}{|c|}{ Actual rating } & \multirow[t]{2}{*}{ Predicted rating range } \\
\hline & $\underline{\mathrm{S} \& \mathrm{P}}$ & Moody's & Fitch & \\
\hline Argentina & $\begin{array}{c}\mathrm{B}+ \\
(\mathrm{Oct}-06)\end{array}$ & $\begin{array}{c}\text { B3 } \\
(\text { Jun-05) }\end{array}$ & $\begin{array}{c}\text { B } \\
(\text { Aug-06) }\end{array}$ & $\mathrm{B}-$ to $\mathrm{BB}$ \\
\hline Armenia & & $\begin{array}{c}\text { Baa3 } \\
(\text { Jul-06) }\end{array}$ & $\begin{array}{c}\text { BB- } \\
\text { (Jun-06) }\end{array}$ & $\mathrm{BB}+$ to $\mathrm{BBB}$ \\
\hline Azerbaijan & & $\begin{array}{c}\text { Baa2 } \\
(\text { Sep-06) }\end{array}$ & $\begin{array}{c}\text { BB } \\
(\text { Nov-04) }\end{array}$ & BB- to BBB- \\
\hline Barbados & $\begin{array}{c}\mathrm{BBB}+ \\
(\text { Aug-04) }\end{array}$ & $\begin{array}{c}\text { Baa2 } \\
(\text { Feb-00) }\end{array}$ & & A \\
\hline Belize & $\begin{array}{c}\text { CC } \\
(\text { Aug-06) }\end{array}$ & $\begin{array}{c}\mathrm{Caa} 3 \\
(\text { Oct-05) }\end{array}$ & & $* * *$ \\
\hline Benin & $\begin{array}{c}\text { B } \\
(\text { Sep-06) }\end{array}$ & & $\begin{array}{c}\text { B } \\
(\text { Sep-04) }\end{array}$ & $\mathrm{CCC}+$ to $\mathrm{B}$ \\
\hline Bolivia & $\begin{array}{c}\text { B- } \\
(\text { Oct-03) }\end{array}$ & $\begin{array}{c}\text { B3 } \\
(\text { Apr-03) }\end{array}$ & $\begin{array}{c}\text { B- } \\
\text { (Jun-05) }\end{array}$ & $\mathrm{B}+$ to $\mathrm{BB}-$ \\
\hline $\begin{array}{l}\text { Bosnia and } \\
\text { Herzegovina }\end{array}$ & & $\begin{array}{c}\text { B2 } \\
(\text { May-06) }\end{array}$ & & $\mathrm{BB}-$ to $\mathrm{BB}$ \\
\hline Botswana & $\begin{array}{c}\mathrm{A} \\
(\text { Apr-01) }\end{array}$ & $\begin{array}{c}\mathrm{Aa3} \\
(\mathrm{May}-06)\end{array}$ & & AA to AAA \\
\hline Brazil & $\begin{array}{c}\text { BB } \\
(\text { Feb-06) }\end{array}$ & $\mathrm{Ba} 2$ (Aug- & $\begin{array}{c}\text { BB } \\
\text { (Jun-06) }\end{array}$ & $\mathrm{BB}$ to $\mathrm{BB}+$ \\
\hline Bulgaria & $\begin{array}{c}\text { BBB+ } \\
(\text { Oct-06) }\end{array}$ & $\begin{array}{c}\text { Baa3 } \\
(\text { Mar-06) }\end{array}$ & $\begin{array}{c}\text { BBB } \\
(\text { Aug-05) }\end{array}$ & BBB- \\
\hline Burkina Faso & $\begin{array}{c}\text { B } \\
(\text { Mar-04) }\end{array}$ & & & $\mathrm{CCC}$ to $\mathrm{B}-$ \\
\hline Cameroon & $\begin{array}{c}\text { B- } \\
(\text { May-06) }\end{array}$ & & $\begin{array}{c}\text { B } \\
(\text { Jun-06) }\end{array}$ & $\mathrm{B}$ to $\mathrm{B}+$ \\
\hline Cape Verde & & & $\begin{array}{c}\mathrm{B}+ \\
(\text { Aug-03) }\end{array}$ & $\mathrm{BB}+$ \\
\hline Chile & $\begin{array}{c}\text { A } \\
(\text { Jan-04) }\end{array}$ & $\begin{array}{c}\text { A2 } \\
(\text { Jul-06) }\end{array}$ & $\begin{array}{c}\text { A } \\
(\text { Mar-05) }\end{array}$ & A to $\mathrm{A}+$ \\
\hline China & $\begin{array}{c}\text { A } \\
(\text { Jul-06) }\end{array}$ & $\begin{array}{c}\text { A2 } \\
(\text { Oct-03) }\end{array}$ & $\begin{array}{c}\text { A } \\
(\text { Oct-05) }\end{array}$ & $\mathrm{BBB}+$ to $\mathrm{A}$ \\
\hline Colombia & $\begin{array}{c}\text { BB } \\
(\text { May-00) }\end{array}$ & $\begin{array}{c}\mathrm{Ba} 2 \\
(\text { Aug-99) }\end{array}$ & $\begin{array}{c}\text { BB } \\
(\text { May-04) }\end{array}$ & $\mathrm{BB}$ to $\mathrm{BB}+$ \\
\hline Costa Rica & $\begin{array}{c}\text { BB } \\
\text { (Jul-97) }\end{array}$ & $\begin{array}{c}\text { Ba1 } \\
\text { (May-97) }\end{array}$ & $\begin{array}{c}\text { BB } \\
(\text { Apr-03) }\end{array}$ & $\mathrm{BBB}$ to $\mathrm{BBB}+$ \\
\hline Croatia & $\begin{array}{c}\text { BBB } \\
(\text { Dec-04) }\end{array}$ & $\begin{array}{c}\mathrm{Baa3} \\
(\mathrm{Jan}-97)\end{array}$ & $\begin{array}{l}\text { BBB- } \\
\text { (Jul-05) }\end{array}$ & $\mathrm{BBB}-$ to $\mathrm{BBB}$ \\
\hline Czech Republic & $\begin{array}{c}\text { A- } \\
(\text { Nov-98) }\end{array}$ & $\begin{array}{c}\text { A1 } \\
(\text { Nov-02) }\end{array}$ & $\begin{array}{c}\text { A } \\
(\text { Aug-05) }\end{array}$ & A- to A \\
\hline Dominican Republic & $\begin{array}{c}\text { B } \\
(\text { Jun-05) }\end{array}$ & $\begin{array}{c}\text { B3 } \\
(\text { Jan-04) }\end{array}$ & $\begin{array}{c}\text { B } \\
(\text { May-06) }\end{array}$ & $\mathrm{B}+$ to $\mathrm{BB}$ \\
\hline Ecuador & $\begin{array}{c}\mathrm{CCC}+ \\
(\text { Oct- } 05)\end{array}$ & $\begin{array}{c}\text { Caal } \\
(\text { Feb-04) }\end{array}$ & $\begin{array}{c}\text { B- } \\
(\text { Aug-05) }\end{array}$ & BB- to BB- \\
\hline
\end{tabular}




\begin{tabular}{|c|c|c|c|c|}
\hline \multirow[t]{2}{*}{ Country } & \multicolumn{3}{|c|}{ Actual rating } & \multirow[t]{2}{*}{ Predicted rating range } \\
\hline & $\underline{S \& P}$ & Moody's & Fitch & \\
\hline Egypt, Arab Rep. & $\begin{array}{c}\mathrm{BB}+ \\
(\mathrm{May}-02)\end{array}$ & $\begin{array}{c}\mathrm{Ba} 1 \\
(\mathrm{Jul}-01)\end{array}$ & $\begin{array}{c}\text { BB+ } \\
(\text { Dec-04) }\end{array}$ & BBB- to BBB \\
\hline El Salvador & $\begin{array}{c}\mathrm{BB}+ \\
(\mathrm{Apr}-99)\end{array}$ & $\begin{array}{c}\text { Baa3 } \\
\text { (Dec-03) }\end{array}$ & $\begin{array}{c}\mathrm{BB}+ \\
(\mathrm{Jan}-05)\end{array}$ & $\mathrm{BB}-$ to $\mathrm{BB}$ \\
\hline Estonia & $\begin{array}{c}\text { A } \\
\text { (Nov-04) }\end{array}$ & $\begin{array}{c}\mathrm{A} 1 \\
(\mathrm{Nov}-02)\end{array}$ & $\underset{(\mathrm{Jul}-04)}{\mathrm{A}}$ & $\mathrm{A}$ to $\mathrm{A}+$ \\
\hline Fiji & $\begin{array}{c}\text { B+ } \\
(\mathrm{Nov}-06)\end{array}$ & $\begin{array}{c}\text { Ba1 } \\
\text { (May-06) }\end{array}$ & & $\mathrm{BB}+$ to $\mathrm{BBB}$ \\
\hline Gambia, The & & & $\begin{array}{c}\text { CCC } \\
(\text { Dec-05) }\end{array}$ & B- to B- \\
\hline Georgia & $\begin{array}{c}\mathrm{B}+ \\
(\mathrm{Dec}-05)\end{array}$ & & & BB- to $\mathrm{BB}$ \\
\hline Ghana & $\begin{array}{c}\mathrm{B}+ \\
(\mathrm{Sep}-03)\end{array}$ & & $\begin{array}{c}\mathrm{B}+ \\
(\mathrm{Mar}-05)\end{array}$ & B- to BB- \\
\hline Grenada & $\begin{array}{c}\text { B- } \\
\text { (Nov-05) }\end{array}$ & & & $* * *$ \\
\hline Guatemala & $\begin{array}{c}\text { BB } \\
(\text { Jul-06) }\end{array}$ & $\begin{array}{c}\mathrm{Ba} 2 \\
\text { (Aug-97) }\end{array}$ & $\begin{array}{c}\mathrm{BB}+ \\
(\mathrm{Feb}-06)\end{array}$ & BB- to $\mathrm{BB}$ \\
\hline Honduras & & $\begin{array}{c}\mathrm{Ba} 3 \\
\text { (May-06) }\end{array}$ & & B to BB- \\
\hline Hungary & $\begin{array}{c}\text { BBB+ } \\
(\text { Jun-06) }\end{array}$ & $\begin{array}{c}\mathrm{A} 1 \\
(\mathrm{Nov}-02)\end{array}$ & $\begin{array}{c}\text { BBB+ } \\
(\text { Dec-05) }\end{array}$ & $\mathrm{BBB}+$ to $\mathrm{A}-$ \\
\hline India & $\mathrm{BB}+(\mathrm{Feb}-05)$ & $\begin{array}{c}\mathrm{Baa} 2 \\
(\mathrm{May}-06)\end{array}$ & $\begin{array}{c}\text { BBB- } \\
\text { (Aug-06) }\end{array}$ & BBB- to BBB \\
\hline Indonesia & $\begin{array}{c}\text { BB- } \\
(\text { Jul-06) }\end{array}$ & $\begin{array}{c}\text { B1 } \\
(\text { May-06) }\end{array}$ & $\begin{array}{c}\text { BB- } \\
(\text { Jan-05) }\end{array}$ & $\mathrm{B}+$ to $\mathrm{BB}-$ \\
\hline Iran, Islamic Rep. & & & $\begin{array}{c}\text { B+ } \\
(\text { Apr-06) }\end{array}$ & $* * *$ \\
\hline Jamaica & $\underset{(\mathrm{Jul}-03)}{\mathrm{B}}$ & $\begin{array}{c}\text { B1 } \\
(\text { May-03) }\end{array}$ & $\begin{array}{c}\mathrm{B}+ \\
\text { (Aug-06) }\end{array}$ & $\mathrm{B}+$ to $\mathrm{BB}+$ \\
\hline Jordan & $\begin{array}{c}\text { BB } \\
(\mathrm{Jul}-03)\end{array}$ & $\begin{array}{c}\mathrm{Baa3} \\
(\mathrm{May}-06)\end{array}$ & & $\mathrm{BBB}$ to $\mathrm{BBB}+$ \\
\hline Kazakhstan & $\begin{array}{c}\text { BBB } \\
(\text { Nov-06) }\end{array}$ & $\begin{array}{c}\text { Baa2 } \\
\text { (Jun-06) }\end{array}$ & $\begin{array}{c}\text { BBB } \\
(\text { Dec-05) }\end{array}$ & $* * *$ \\
\hline Kenya & $\begin{array}{c}\mathrm{B}+ \\
(\mathrm{Sep}-06)\end{array}$ & & & B- to $B$ \\
\hline Latvia & $\begin{array}{c}\text { A- } \\
(\text { Jul-04) }\end{array}$ & $\begin{array}{c}\text { A2 } \\
\text { (Nov-02) }\end{array}$ & $\begin{array}{c}\text { A- } \\
\text { (Aug-05) }\end{array}$ & $\mathrm{BBB}$ to $\mathrm{A}$ \\
\hline Lebanon & $\begin{array}{c}\text { B- } \\
(\text { Apr-02) }\end{array}$ & $\begin{array}{c}\text { B3 } \\
(\text { Mar-05) }\end{array}$ & $\begin{array}{c}\text { B- } \\
\text { (Nov-05) }\end{array}$ & *** \\
\hline Lesotho & & & $\begin{array}{c}\text { BB- } \\
(\text { Nov-05) }\end{array}$ & $\mathrm{BB}-$ to $\mathrm{BB}+$ \\
\hline Lithuania & $\begin{array}{c}\mathrm{A} \\
(\mathrm{Dec}-05)\end{array}$ & $\begin{array}{c}\mathrm{A} 2 \\
(\mathrm{Sep}-06)\end{array}$ & $\begin{array}{c}\text { A } \\
(\text { Oct-06) }\end{array}$ & A- to A \\
\hline Macedonia, FYR & $\begin{array}{c}\text { BB+ } \\
\text { (Aug-05) }\end{array}$ & & $\begin{array}{c}\text { BB+ } \\
(\text { Dec-05) }\end{array}$ & BB to BBB- \\
\hline
\end{tabular}




\begin{tabular}{|c|c|c|c|c|}
\hline \multirow[t]{2}{*}{ Country } & \multicolumn{3}{|c|}{ Actual rating } & \multirow[t]{2}{*}{ Predicted rating range } \\
\hline & $\underline{S \& P}$ & Moody's & Fitch & \\
\hline Madagascar & $\begin{array}{c}\text { B } \\
\text { (May-04) }\end{array}$ & & & $* * *$ \\
\hline Malawi & & & $\begin{array}{c}\text { CCC } \\
(\text { Dec-05) }\end{array}$ & $\mathrm{CC}$ or lower \\
\hline Malaysia & $\begin{array}{c}\text { A- } \\
(\text { Oct-03) }\end{array}$ & $\begin{array}{c}\mathrm{A} 3 \\
(\mathrm{Dec}-04)\end{array}$ & $\begin{array}{c}\text { A- } \\
\text { (Nov-04) }\end{array}$ & A- to A \\
\hline Mali & $\begin{array}{c}\text { B } \\
\text { (May-04) }\end{array}$ & & $\begin{array}{c}\text { B- } \\
(\text { Apr-04) }\end{array}$ & $\mathrm{B}$ to $\mathrm{B}$ \\
\hline Mauritius & & $\begin{array}{c}\text { Baa1 } \\
\text { (May-06) }\end{array}$ & & A- \\
\hline Mexico & $\begin{array}{c}\text { BBB } \\
(\text { Jan-05) }\end{array}$ & $\begin{array}{c}\text { Baal } \\
(\text { Jan-05) }\end{array}$ & $\begin{array}{c}\text { BBB } \\
\text { (Dec-05) }\end{array}$ & $\mathrm{BB}+$ to $\mathrm{BBB}-$ \\
\hline Moldova & & $\begin{array}{c}\text { Caa1 } \\
\text { (May-03) }\end{array}$ & $\begin{array}{c}\text { B- } \\
(\mathrm{Feb}-03)\end{array}$ & $\mathrm{B}+$ to $\mathrm{BB}$ \\
\hline Mongolia & $\begin{array}{c}\text { B } \\
\text { (Dec-99) }\end{array}$ & $\begin{array}{c}\mathrm{Ba} 2 \\
\text { (May-06) }\end{array}$ & $\begin{array}{c}\mathrm{B}+ \\
(\mathrm{Jul}-05)\end{array}$ & $\mathrm{BB}-$ to $\mathrm{BB}$ \\
\hline Morocco & $\begin{array}{c}\text { BB+ } \\
\text { (Aug-05) }\end{array}$ & $\begin{array}{c}\text { Ba1 } \\
\text { (Jul-99) }\end{array}$ & & BBB- to BBB \\
\hline Mozambique & $\begin{array}{c}\text { B } \\
(\mathrm{Jul}-04)\end{array}$ & & $\begin{array}{c}\text { B } \\
(\text { Jul-03) }\end{array}$ & $\mathrm{B}$ - to $\mathrm{B}$ \\
\hline Namibia & & & $\begin{array}{l}\text { BBB- } \\
\text { (Dec-05) }\end{array}$ & $\mathrm{BB}+$ to $\mathrm{BBB}$ \\
\hline Nicaragua & $\begin{array}{c}\text { BB- } \\
\text { (Feb-06) }\end{array}$ & $\begin{array}{c}\text { B3 } \\
\text { (May-06) }\end{array}$ & & $\mathrm{CCC}+$ to $\mathrm{B}$ \\
\hline Nigeria & $\begin{array}{c}\text { BB- } \\
\text { (Feb-06) }\end{array}$ & & $\begin{array}{c}\text { BB- } \\
(\mathrm{Jan}-06)\end{array}$ & $\mathrm{B}+$ to $\mathrm{BB}-$ \\
\hline Oman & $\begin{array}{c}\text { A- } \\
(\text { Sep-06) }\end{array}$ & $\begin{array}{c}\text { A1 } \\
\text { (Oct-06) }\end{array}$ & & A- to $\mathrm{A}+$ \\
\hline Pakistan & $\begin{array}{c}\text { B+ } \\
(\text { Nov-04) }\end{array}$ & $\begin{array}{c}\text { B1 } \\
\text { (Nov-06) }\end{array}$ & & $\mathrm{B}$ to $\mathrm{B}+$ \\
\hline Panama & $\begin{array}{c}\text { BB } \\
(\text { Nov-01) }\end{array}$ & $\begin{array}{c}\text { Ba1 } \\
(\text { Jan-97) }\end{array}$ & $\begin{array}{c}\mathrm{BB}+ \\
(\mathrm{Dec}-03)\end{array}$ & $\mathrm{BB}+$ to $\mathrm{BB}+$ \\
\hline Papua New Guinea & $\frac{\text { B }}{(\text { Aug-01) }}$ & $\begin{array}{c}\mathrm{Ba} 2 \\
(\text { May-06) }\end{array}$ & $\begin{array}{c}\text { B } \\
(\text { Jul-03) }\end{array}$ & B- to BB \\
\hline Paraguay & $\begin{array}{c}\text { B- } \\
(\text { Jul-04) }\end{array}$ & $\begin{array}{c}\text { B3 } \\
\text { (May-06) }\end{array}$ & & $\mathrm{B}$ to $\mathrm{B}^{+}$ \\
\hline Peru & $\begin{array}{c}\text { BB+ } \\
\text { (Nov-06) }\end{array}$ & $\begin{array}{c}\mathrm{Ba3} \\
(\mathrm{Jul}-99)\end{array}$ & $\begin{array}{c}\text { BB }+ \\
\text { (Aug-06) }\end{array}$ & $\mathrm{BB}$ to $\mathrm{BB}+$ \\
\hline Philippines & $\begin{array}{c}\text { BB- } \\
(\text { Jan-05) }\end{array}$ & $\begin{array}{c}\text { B1 } \\
\text { (Feb-05) }\end{array}$ & $\begin{array}{c}\text { BB } \\
(\text { Jul-05) }\end{array}$ & $\mathrm{BB}-$ to $\mathrm{BB}$ \\
\hline Poland & $\begin{array}{c}\text { BBB+ } \\
\text { (May-00) }\end{array}$ & $\begin{array}{c}\mathrm{A} 2 \\
(\mathrm{Nov}-02)\end{array}$ & $\begin{array}{c}\text { BBB+ } \\
\text { (Mar-05) }\end{array}$ & $\mathrm{BBB}+$ \\
\hline Romania & $\begin{array}{c}\text { BBB- } \\
\text { (Sep-05) }\end{array}$ & $\begin{array}{c}\text { Baa3 } \\
\text { (Oct-06) }\end{array}$ & $\begin{array}{c}\text { BBB } \\
\text { (Aug-06) }\end{array}$ & BBB \\
\hline Russian Federation & $\begin{array}{c}\text { BBB+ } \\
\text { (Sep-06) }\end{array}$ & $\begin{array}{c}\text { Baa2 } \\
\text { (Oct-05) }\end{array}$ & $\begin{array}{c}\text { BBB+ } \\
(\text { Jul-06) }\end{array}$ & $\mathrm{BB}$ to $\mathrm{BBB}+$ \\
\hline
\end{tabular}




\begin{tabular}{|c|c|c|c|c|}
\hline \multirow[t]{2}{*}{ Country } & \multicolumn{3}{|c|}{ Actual rating } & \multirow[t]{2}{*}{ Predicted rating range } \\
\hline & $\underline{\mathbf{S} \& \mathbf{P}}$ & Moody's & $\underline{\text { Fitch }}$ & \\
\hline Senegal & $\begin{array}{c}\text { B+ } \\
(\text { Dec-00) }\end{array}$ & & & $\mathrm{B}$ to $\mathrm{B}+$ \\
\hline Serbia and Montenegro & $\begin{array}{c}\text { BB- } \\
(\text { Jul-05) }\end{array}$ & & $\begin{array}{c}\text { BB- } \\
\text { (May-05) }\end{array}$ & $\mathrm{B}$ - to $\mathrm{BB}$ \\
\hline Seychelles & $\begin{array}{c}\text { B } \\
(\text { Sep-06) }\end{array}$ & & & BB- to $\mathrm{BBB}+$ \\
\hline Slovak Republic & $\begin{array}{c}\text { A } \\
(\text { Dec-05) }\end{array}$ & $\begin{array}{c}\text { A1 } \\
\text { (Oct-06) }\end{array}$ & $\begin{array}{c}\text { A } \\
(\text { Oct-05) }\end{array}$ & A- \\
\hline South Africa & $\begin{array}{c}\text { BBB+ } \\
\text { (Aug-05) }\end{array}$ & $\begin{array}{c}\text { Baa1 } \\
(\text { Jan-05) }\end{array}$ & $\begin{array}{c}\text { BBB+ } \\
\text { (Aug-05) }\end{array}$ & $\mathrm{BBB}+$ \\
\hline Sri Lanka & $\begin{array}{c}\mathrm{B}+ \\
(\mathrm{Dec}-05)\end{array}$ & & $\begin{array}{c}\text { BB- } \\
(\text { Dec-05) }\end{array}$ & $\mathrm{BB}-$ to $\mathrm{BB}$ \\
\hline Suriname & $\begin{array}{c}\text { B- } \\
\text { (Aug-04) }\end{array}$ & $\begin{array}{c}\mathrm{Ba} 2 \\
(\text { May-06) }\end{array}$ & $\begin{array}{c}\text { B } \\
(\text { Jun-04) }\end{array}$ & $\mathrm{BB}+$ to $\mathrm{BBB}-$ \\
\hline Thailand & $\begin{array}{c}\text { BBB+ } \\
\text { (Aug-04) }\end{array}$ & $\begin{array}{c}\text { Baa1 } \\
\text { (Nov-03) }\end{array}$ & $\begin{array}{c}\text { BBB+ } \\
(\text { May-05) }\end{array}$ & $\mathrm{BBB}$ to $\mathrm{BBB}+$ \\
\hline Trinidad and Tobago & $\begin{array}{c}\text { A- } \\
(\text { Jul-05) }\end{array}$ & $\begin{array}{c}\text { Baa1 } \\
(\text { Jul-06) }\end{array}$ & & $\mathrm{BBB}+$ to $\mathrm{A}$ \\
\hline Tunisia & $\begin{array}{c}\text { BBB } \\
(\text { Mar-00) }\end{array}$ & $\begin{array}{c}\text { A3 } \\
\text { (May-06) }\end{array}$ & $\begin{array}{c}\text { BBB } \\
(\text { May-01) }\end{array}$ & BBB- to BBB \\
\hline Turkey & $\begin{array}{c}\text { BB- } \\
\text { (Aug-04) }\end{array}$ & $\begin{array}{c}\mathrm{Ba} 3 \\
(\mathrm{Dec}-05)\end{array}$ & $\begin{array}{c}\text { BB- } \\
(\text { Dec-05) }\end{array}$ & $\mathrm{BB}+$ to $\mathrm{BBB}-$ \\
\hline Turkmenistan & & $\begin{array}{c}\text { B1 } \\
\text { (May-06) }\end{array}$ & $\begin{array}{c}\text { CCC- } \\
(\text { May-01) }\end{array}$ & $\mathrm{BB}$ to $\mathrm{A}$ \\
\hline Uganda & & & $\begin{array}{c}\text { B } \\
(\text { Mar-05) }\end{array}$ & $\mathrm{CCC}$ to $\mathrm{B}-$ \\
\hline Ukraine & $\begin{array}{c}\text { BB- } \\
\text { (May-05) }\end{array}$ & $\begin{array}{c}\text { B1 } \\
\text { (Nov-03) }\end{array}$ & $\begin{array}{c}\text { BB- } \\
(\text { Jun-05) }\end{array}$ & $\mathrm{BB}$ to $\mathrm{BB}+$ \\
\hline Uruguay & $\begin{array}{c}\mathrm{B}+ \\
(\mathrm{Sep}-06)\end{array}$ & $\begin{array}{c}\text { B3 } \\
(\text { Jul-02) }\end{array}$ & $\begin{array}{c}\mathrm{B}+ \\
(\mathrm{Mar}-05)\end{array}$ & $* * *$ \\
\hline Venezuela, RB & $\begin{array}{c}\text { BB- } \\
(\text { Feb-06) }\end{array}$ & $\begin{array}{c}\text { B2 } \\
\text { (Sep-04) }\end{array}$ & $\begin{array}{c}\text { BB- } \\
(\text { Nov-05) }\end{array}$ & BB- \\
\hline Vietnam & $\begin{array}{c}\text { BB } \\
(\text { Sep-06) }\end{array}$ & $\begin{array}{c}\mathrm{Ba3} \\
(\mathrm{Jul}-05)\end{array}$ & $\begin{array}{c}\text { BB- } \\
\text { (Nov-03) }\end{array}$ & BB \\
\hline
\end{tabular}

* The actual ratings are the latest available as of December 6, 2006. The dates when the ratings were established are shown in parentheses. The model-based ratings should be treated as indicative; they are clearly not a substitute for the broader and deeper analysis, and qualitative judgment, employed by experienced rating analysts. The predicted ratings range is based on predictions for the benchmark models for S\&P, Moody's and Fitch. Dated explanatory variables were used for predicting ratings for 2006. Note that these shadow ratings are not predictions for future rating changes. For that one would need forecasts for the explanatory variables.

** When the predicted rating was above 21 in the numeric scale, we classified it as out of range.

*** Outliers excluded from prediction model.

Source: Authors'calculations. 
Annex table 2: Contribution of explanatory variables to predicted S\&P ratings for unrated countries

\begin{tabular}{|c|c|c|c|c|c|c|c|c|c|c|c|c|c|}
\hline \multirow[b]{2}{*}{ Country } & \multirow[b]{2}{*}{$\begin{array}{l}\text { Predicted } \\
\text { rating using } \\
\text { S\&P } \\
\text { regression* }\end{array}$} & \multicolumn{6}{|c|}{ Explanatory variables as of end-2005 } & \multicolumn{6}{|c|}{$\begin{array}{c}\text { Contribution to rating } \\
\text { (Deviation from mean rating of } B ; \text { a negative number indicates } \\
\text { a better than average rating) }\end{array}$} \\
\hline & & $\begin{array}{l}\text { GDP } \\
\text { growth }\end{array}$ & $\begin{array}{l}\text { GNI } \\
\text { per } \\
\text { capita }\end{array}$ & $\begin{array}{l}\text { Ratio of } \\
\text { reserves to } \\
\text { import \& } \\
\text { short-term } \\
\text { debt }\end{array}$ & $\begin{array}{l}\text { Ratio of } \\
\text { ext. } \\
\text { debt to } \\
\text { exports }\end{array}$ & $\begin{array}{l}\text { GDP } \\
\text { volatility } \\
\text { (5-yr } \\
\text { std. } \\
\text { dev.) } \\
\end{array}$ & $\begin{array}{l}\text { Rule } \\
\text { of law }\end{array}$ & $\begin{array}{l}\text { GDP } \\
\text { growth }\end{array}$ & $\begin{array}{l}\text { Log of } \\
\text { GNI } \\
\text { per } \\
\text { capita }\end{array}$ & $\begin{array}{l}\text { Ratio of } \\
\text { res. to } \\
\text { import \& } \\
\text { ST debt }\end{array}$ & $\begin{array}{l}\text { Ratio of } \\
\text { ext. debt } \\
\text { to exports }\end{array}$ & $\begin{array}{l}\text { GDP } \\
\text { volatility } \\
\text { (5-yr } \\
\text { std. } \\
\text { dev.) }\end{array}$ & $\begin{array}{l}\text { Rule } \\
\text { of law }\end{array}$ \\
\hline Albania & BB & 5.7 & 2,580 & 0.3 & 0.8 & 1.5 & -0.8 & -0.7 & -1.7 & 0.6 & -1.5 & -0.5 & 0.3 \\
\hline Algeria & AA- & 5.9 & 2,730 & 2.3 & 0.6 & 1.7 & -0.7 & -0.8 & -1.8 & -6.1 & -1.7 & -0.5 & 0 \\
\hline Angola & $\mathrm{B}+$ & 9.8 & 1,350 & 0.2 & 0.6 & 5.7 & -1.3 & -2.6 & -0.8 & 1.2 & -1.7 & 1 & 1.5 \\
\hline Bangladesh & $B$ & 5.7 & 470 & 0.2 & 1.9 & 0.7 & -0.9 & -0.7 & 0.7 & 1.1 & -0.7 & -0.8 & 0.4 \\
\hline Belarus & $\mathrm{BB}+$ & 9.2 & 2,760 & 0.1 & 0.3 & 2.9 & -1 & -2.4 & -1.8 & 1.5 & -1.9 & 0 & 0.8 \\
\hline Bhutan & $\mathrm{BBB}+$ & 6.8 & 870 & 1 & 2.6 & 1.1 & 0.5 & -1.2 & -0.2 & -1.6 & -0.3 & -0.7 & -3.2 \\
\hline Burundi & $\star \star$ & 1.5 & 100 & 0.3 & 22.4 & 2.5 & -1.2 & 1.3 & 2.9 & 0.6 & 13.1 & -0.2 & 1.2 \\
\hline Cambodia & $\mathrm{B}+$ & 7.3 & 380 & 0.3 & 0.6 & 1.1 & -1.1 & -1.4 & 1 & 0.9 & -1.6 & -0.7 & 1.1 \\
\hline Cen. Afr. Rep. & $\star *$ & -1.4 & 350 & 0.6 & 6.5 & 4 & -1.3 & 2.6 & 1.1 & -0.1 & 2.3 & 0.4 & 1.5 \\
\hline Chad & $\mathrm{B}+$ & 16.7 & 400 & 0.1 & 0.5 & 9.4 & -1.2 & -5.9 & 0.9 & 1.4 & -1.7 & 2.4 & 1.3 \\
\hline Comoros & $\mathrm{CCC}$ & 2.3 & 640 & 0.4 & 5 & 0.3 & -1 & 0.9 & 0.2 & 0.4 & 1.3 & -1 & 0.6 \\
\hline Congo, Dem. Rep. & $C$ & 6.4 & 120 & 0.1 & 4 & 3.7 & -1.4 & -1 & 2.6 & 1.6 & 0.7 & 0.3 & 1.8 \\
\hline Congo, Rep. & $\mathrm{CCC}+$ & 4.5 & 950 & 0.3 & 1.5 & 3 & -1.8 & -0.2 & -0.3 & 0.9 & -1 & 0 & 2.7 \\
\hline Cote d'Ivoire & $\mathrm{CCC}-$ & -0.1 & 840 & 0.2 & 2 & 1.4 & -1.5 & 2 & -0.1 & 1.1 & -0.7 & -0.6 & 2 \\
\hline Djibouti & B & 3.1 & 1,020 & 0.2 & 1.7 & 0.5 & -0.9 & 0.5 & -0.4 & 1.1 & -0.9 & -0.9 & 0.4 \\
\hline Dominica & $\mathrm{BB}+$ & 1.7 & 3,790 & 0.2 & 1.5 & 3.6 & 0.7 & 1.2 & -2.3 & 1 & -1 & 0.2 & -3.6 \\
\hline Equatorial Guinea & BBB- & 10.2 & 6,205 & 0.6 & 0 & 6.5 & -1.3 & -2.8 & -3 & -0.3 & -2 & 1.3 & 1.6 \\
\hline Eritrea & ** & 3.6 & 220 & 0 & 8.2 & 3.3 & -0.8 & 0.3 & 1.7 & 1.6 & 3.5 & 0.1 & 0.2 \\
\hline Ethiopia & CCC- & 6 & 160 & 0.3 & 3.4 & 6.4 & -0.8 & -0.8 & 2.2 & 0.8 & 0.2 & 1.3 & 0.1 \\
\hline Gabon & $\mathrm{BB}+$ & 2.1 & 5,010 & 0.2 & 0.2 & 1.1 & -0.5 & 1 & -2.7 & 1 & -1.9 & -0.7 & -0.6 \\
\hline Guinea & $\mathrm{CCC}-$ & 2.3 & 370 & 0.1 & 3.4 & 1.2 & -1.1 & 0.9 & 1 & 1.3 & 0.3 & -0.7 & 1 \\
\hline Guinea-Bissau & C & 2.1 & 180 & 0.5 & 4.4 & 4.1 & -1.3 & 1 & 2 & 0.1 & 1 & 0.4 & 1.6 \\
\hline Guyana & $\mathrm{CCC}+$ & -0.6 & 1,010 & 0.3 & 1.7 & 2.1 & -0.8 & 2.3 & -0.4 & 0.9 & -0.9 & -0.3 & 0.2 \\
\hline Haiti & CC & -0.3 & 450 & 0.1 & 2.2 & 1.5 & -1.6 & 2.1 & 0.7 & 1.5 & -0.5 & -0.5 & 2.4 \\
\hline Kiribati & AAA & 0.4 & 1,390 & 5.3 & 2.1 & 2.7 & 0.8 & 1.8 & -0.9 & -16.4 & -0.6 & -0.1 & -3.8 \\
\hline Kyrgyz Republic & $\mathrm{CCC}+$ & 4.5 & 440 & 0.4 & 2.2 & 3.8 & -1.1 & -0.1 & 0.8 & 0.3 & -0.6 & 0.3 & 0.9 \\
\hline Lao PDR & B- & 6.5 & 440 & 0.3 & 3.7 & 0.5 & -1.1 & -1.1 & 0.8 & 0.9 & 0.5 & -0.9 & 1.1 \\
\hline Liberia & $\star *$ & -7.8 & 130 & 0 & 5.9 & 15.7 & -1.6 & 5.6 & 2.5 & 1.7 & 1.9 & 4.7 & 2.3 \\
\hline Libya & AAA & 5.7 & 5,530 & 3.2 & 0.2 & 2.4 & -0.7 & -0.7 & -2.8 & -9.2 & -1.9 & -0.2 & 0 \\
\hline
\end{tabular}




\begin{tabular}{|c|c|c|c|c|c|c|c|c|c|c|c|c|c|}
\hline \multirow[b]{2}{*}{ Country } & \multirow[b]{2}{*}{$\begin{array}{l}\text { Predicted } \\
\text { rating using } \\
\text { S\&P } \\
\text { regression* }\end{array}$} & \multicolumn{6}{|c|}{ Explanatory variables as of end-2005 } & \multicolumn{6}{|c|}{$\begin{array}{c}\text { Contribution to rating } \\
\text { (Deviation from mean rating of B; a negative number indicates a } \\
\text { better than average rating) }\end{array}$} \\
\hline & & $\begin{array}{l}\text { GDP } \\
\text { growth }\end{array}$ & $\begin{array}{l}\text { GNI } \\
\text { per } \\
\text { capita }\end{array}$ & $\begin{array}{l}\text { Ratio of } \\
\text { reserves to } \\
\text { import \& } \\
\text { short-term } \\
\text { debt }\end{array}$ & $\begin{array}{l}\text { Ratio of } \\
\text { ext. debt } \\
\text { to } \\
\text { exports }\end{array}$ & $\begin{array}{l}\text { GDP } \\
\text { volatility } \\
\text { (5-yr std. } \\
\text { dev.) }\end{array}$ & $\begin{array}{l}\text { Rule } \\
\text { of law }\end{array}$ & $\begin{array}{l}\text { GDP } \\
\text { growth }\end{array}$ & $\begin{array}{l}\text { Log of } \\
\text { GNI } \\
\text { per } \\
\text { capita }\end{array}$ & $\begin{array}{l}\text { Ratio of } \\
\text { res. to } \\
\text { import \& } \\
\text { ST debt }\end{array}$ & $\begin{array}{l}\text { Ratio of ext. } \\
\text { debt to } \\
\text { exports }\end{array}$ & $\begin{array}{l}\text { GDP } \\
\text { volatility } \\
\text { (5-yr std. } \\
\text { dev.) }\end{array}$ & $\begin{array}{l}\text { Rule } \\
\text { of law }\end{array}$ \\
\hline Maldives & $\mathrm{BB}+$ & 4.6 & 2,390 & 0.2 & 1.1 & 5.1 & 0.3 & -0.2 & -1.6 & 1.1 & -1.3 & 0.8 & -2.7 \\
\hline Marshall Islands & B & 1.9 & 2,930 & 0 & 3.6 & 2 & -0.3 & 1.1 & -1.9 & 1.7 & 0.4 & -0.4 & -1.2 \\
\hline Mauritania & $\mathrm{B}$ & 6.2 & 560 & 0.2 & 3.7 & 1.9 & -0.5 & -1 & 0.4 & 0.9 & 0.4 & -0.4 & -0.5 \\
\hline Myanmar & CCC- & 7.3 & 219 & 0.2 & 2 & 4.7 & -1.6 & -1.4 & 1.7 & 1 & -0.7 & 0.7 & 2.2 \\
\hline Nepal & $\mathrm{CCC}+$ & 3 & 270 & 0.7 & 3.1 & 2.3 & -0.8 & 0.5 & 1.5 & -0.7 & 0 & -0.3 & 0.2 \\
\hline Niger & $\mathrm{CCC}$ & 3.3 & 240 & 0.3 & 3.4 & 2.7 & -0.8 & 0.4 & 1.6 & 0.7 & 0.3 & -0.1 & 0.3 \\
\hline Rwanda & C & 3.3 & 230 & 0.6 & 7.4 & 3.2 & -1 & 0.4 & 1.7 & -0.3 & 3 & 0.1 & 0.7 \\
\hline Samoa & BB- & 3.6 & 2,090 & 0.1 & 6.7 & 2 & 1.1 & 0.3 & -1.4 & 1.3 & 2.5 & -0.4 & -4.7 \\
\hline Sao Tome \& Principe & $\star *$ & 3.6 & 390 & 0.3 & 11.4 & 0.4 & -0.6 & 0.3 & 0.9 & 0.6 & 5.7 & -0.9 & -0.2 \\
\hline Sierra Leone & CCC- & 8 & 220 & 0.3 & 2.4 & 8.7 & -1.1 & -1.8 & 1.7 & 0.7 & -0.4 & 2.1 & 1.1 \\
\hline Solomon Islands & B- & 5.2 & 590 & 0.5 & 1.3 & 6.4 & -0.9 & -0.5 & 0.4 & -0.1 & -1.2 & 1.3 & 0.5 \\
\hline St. Kitts and Nevis & A- & 4.5 & 8,210 & 0.2 & 1.3 & 2 & 0.8 & -0.1 & -3.4 & 1 & -1.2 & -0.3 & -4 \\
\hline St. Lucia & BBB & 3.9 & 4,800 & 0.2 & 1.1 & 3.7 & 0.8 & 0.2 & -2.6 & 1.1 & -1.3 & 0.3 & -4 \\
\hline St. Vincent \& Gren, & BBB & 5.1 & 3,590 & 0.1 & 1.4 & 2.6 & 0.8 & -0.4 & -2.2 & 1.3 & -1.1 & -0.1 & -4 \\
\hline Sudan & $\mathrm{CCC}$ & 6.3 & 640 & 0.3 & 4.9 & 1.1 & -1.5 & -1 & 0.2 & 0.6 & 1.3 & -0.7 & 2 \\
\hline Swaziland & BB- & 2.1 & 2,280 & 0.1 & 0.3 & 0.5 & -0.8 & 1 & -1.6 & 1.4 & -1.9 & -0.9 & 0.1 \\
\hline Syria & A- & 3.2 & 1,380 & 1.9 & 0.5 & 1.6 & -0.4 & 0.5 & -0.8 & -4.9 & -1.7 & -0.5 & -0.8 \\
\hline Tajikistan & $\mathrm{B}+$ & 9.4 & 330 & 0.1 & 1 & 1.3 & -1 & -2.5 & 1.2 & 1.4 & -1.4 & -0.6 & 0.7 \\
\hline Tanzania & $\mathrm{B}+$ & 6.9 & 340 & 0.6 & 3.5 & 0.4 & -0.5 & -1.3 & 1.1 & -0.2 & 0.3 & -0.9 & -0.6 \\
\hline Togo & $\mathrm{CcC}$ & 2.8 & 350 & 0.2 & 2.2 & 1.6 & -1.1 & 0.6 & 1.1 & 1.1 & -0.6 & -0.5 & 0.9 \\
\hline Tonga & $\mathrm{BB}$ & 2.3 & 2,190 & 0.4 & 3.9 & 0.5 & 0.5 & 0.9 & -1.5 & 0.6 & 0.6 & -0.9 & -3 \\
\hline Uzbekistan & BB- & 6.3 & 510 & 0.8 & 0.9 & 1.8 & -1.3 & -1 & 0.6 & -1 & -1.5 & -0.4 & 1.5 \\
\hline Vanuatu & $\mathrm{BB}+$ & 4.1 & 1,600 & 0.3 & 0.6 & 4.7 & 0.5 & 0.1 & -1.1 & 0.6 & -1.7 & 0.6 & -3.2 \\
\hline Yemen, Rep. & $\mathrm{BB}$ & 6.5 & 600 & 1.2 & 1.7 & 3.7 & -1.1 & -1.1 & 0.3 & -2.5 & -0.9 & 0.3 & 1 \\
\hline Zambia & $\mathrm{CCC}+$ & 5.2 & 490 & 0.3 & 6.4 & 0.8 & -0.6 & -0.5 & 0.6 & 0.8 & 2.3 & -0.8 & -0.2 \\
\hline Zimbabwe & $\star \star *$ & -7.2 & 340 & 0 & 1 & 3 & -1.5 & 5.4 & 1.1 & 1.7 & -1.4 & 0 & 2 \\
\hline
\end{tabular}

* The shadow ratings for 2006 reported here are predictions from the benchmark model for S\&P using dated explanatory variables described in table 4 . These model-based ratings should be treated as indicative; they are clearly not a substitute for the broader and deeper analysis, and qualitative judgment, employed by experienced rating analysts. ** When the predicted rating was above 21 in the numeric scale, we classified it as out of range.

Source: Authors' calculations using S\&P model in benchmark Specification 2. 